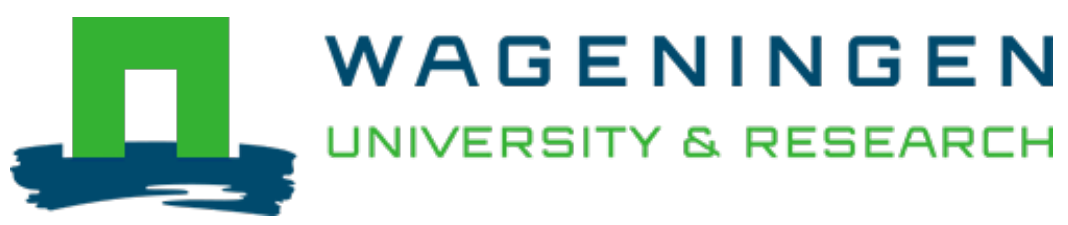

\title{
Yield gap analysis in dairy production systems using the mechanistic model LiGAPS-Dairy
}

\author{
Journal of Dairy Science \\ Linden, Aart; Oosting, Simon J.; Ven, Gerrie W.J.; Zom, Ronald; Ittersum, Martin K. et al \\ https://doi.org/10.3168/jds.2020-19078
}

This article is made publicly available in the institutional repository of Wageningen University and Research, under the terms of article $25 \mathrm{fa}$ of the Dutch Copyright Act, also known as the Amendment Taverne. This has been done with explicit consent by the author.

Article 25 fa states that the author of a short scientific work funded either wholly or partially by Dutch public funds is entitled to make that work publicly available for no consideration following a reasonable period of time after the work was first published, provided that clear reference is made to the source of the first publication of the work.

This publication is distributed under The Association of Universities in the Netherlands (VSNU) 'Article $25 \mathrm{fa}$ implementation' project. In this project research outputs of researchers employed by Dutch Universities that comply with the legal requirements of Article $25 \mathrm{fa}$ of the Dutch Copyright Act are distributed online and free of cost or other barriers in institutional repositories. Research outputs are distributed six months after their first online publication in the original published version and with proper attribution to the source of the original publication.

You are permitted to download and use the publication for personal purposes. All rights remain with the author(s) and / or copyright owner(s) of this work. Any use of the publication or parts of it other than authorised under article $25 \mathrm{fa}$ of the Dutch Copyright act is prohibited. Wageningen University \& Research and the author(s) of this publication shall not be held responsible or liable for any damages resulting from your (re)use of this publication.

For questions regarding the public availability of this article please contact openscience.library@,wur.nl 


\title{
Yield gap analysis in dairy production systems using the mechanistic model LiGAPS-Dairy
}

\author{
Aart van der Linden, ${ }^{1,2 *}$ ๑ Simon J. Oosting, ${ }^{1}$ Gerrie W. J. van de Ven, ${ }^{2} \odot$ Ronald Zom, ${ }^{3}$ \\ Martin K. van Ittersum, ${ }^{2}$ (1) Pierre J. Gerber, ${ }^{1,4}$ and Imke J. M. de Boer ${ }^{1}$ (i) \\ ${ }^{1}$ Animal Production Systems group, Wageningen University \& Research, PO Box 338, 6700 AH Wageningen, the Netherlands \\ ${ }^{2}$ Plant Production Systems group, Wageningen University \& Research, PO Box 430, 6700 AK Wageningen, the Netherlands \\ ${ }^{3}$ Animal Nutrition Group, Wageningen Livestock Research, Wageningen University \& Research, PO Box 338, 6700 AH Wageningen, \\ the Netherlands \\ ${ }^{4}$ The World Bank, Agriculture and Food Global Practice, Radnička cesta 80/IX, HR-10000 Zagreb, Croatia
}

\begin{abstract}
The difference between the theoretical maximum (potential) production and the actual production realized by farmers is referred to as the yield gap. The objectives of this study are to develop a mechanistic model for dairy cows that allows yield gap analysis in dairy production systems and to evaluate model performance. We extended and adapted an existing model for beef cattle to dairy cattle, and the new model was named Livestock simulator for Generic analysis of Animal Production Systems-Dairy cattle (LiGAPS-Dairy). Milk production and growth of an individual cow over its entire lifespan were described as a function of the animal's genotype, the ambient climate, feed quality, and available feed quantity. The model was parameterized for Holstein-Friesian cows. After calibration, we evaluated model performance by comparing simulated results and measured results from experimental farms in the Netherlands, which were not used for model calibration. Cows were permanently housed in stables, where the diet consisted of predetermined amounts of concentrates and ad libitum high-quality roughage. The mean absolute error (MAE) for simulated milk production per lactation was $12 \%$ of the measured milk production, whereas the MAE for simulated daily milk yields was 19\%. The MAE for simulated feed intake per lactation was $10 \%$ of the measured feed intake, whereas the MAE for simulated daily feed intake was $19 \%$. The average yield gap for dairy cows was $11 \%$ of the potential milk production $\left(\mathrm{Y}_{\mathrm{P}}\right)$. Yield gap analysis indicated that for experimental farms in the Netherlands, the difference between $Y_{P}$ and feed quality limited milk
\end{abstract}

Received June 11, 2020.

Accepted December 21, 2020.

*Corresponding author: aart.vanderlinden@wur.nl production $\left(\mathrm{Y}_{\mathrm{L}}\right)$ of 1,009 kg fat- and protein-corrected milk was mainly explained by feed intake capacity $(33 \%)$, protein deficiency $(25 \%)$, cow weight at the start of experiments (23\%), and heat stress (19\%). The LiGAPS-Dairy model also indicated the periods during lactation in which these factors affected milk production. In our opinion, the overall model performance is acceptable for permanently housed cows under Dutch conditions. The model needs to be evaluated further for other production systems, countries and breeds. Thereafter, LiGAPS-Dairy can be used for yield gap analysis and exploration of options to increase resource use efficiency in dairy production.

Key words: cattle, cow, milk, production ecology, model evaluation

\section{INTRODUCTION}

Milk production and feed intake per animal differ considerably among dairy production systems across the globe (Gerber et al., 2011; Britt et al., 2018). Differences in milk production practices are induced by differences in biophysical, socioeconomic, and cultural factors. Disentangling biophysical factors from other factors allows assessment of production based on biological and physical laws only and helps to identify management factors to increase production. These laws can be used to assess the theoretical scope for increasing resource use efficiency and production. Such assessments are facilitated by a framework with a hierarchy in biophysical factors that influence agricultural production. This framework is known as concepts of production ecology (van de Ven et al., 2003).

Concepts of production ecology distinguish defining, limiting, and reducing factors for livestock production. The genotype of an animal and its ambient climate are the defining factors for livestock growth and production. Drinking water and feed (both feed quality and available feed quantity) are limiting factors, and 
van der Linden et al.: MODELING YIELD GAPS IN DAIRY PRODUCTION

diseases, pests, and stress are reducing factors (van de Ven et al., 2003; van der Linden et al., 2015). The biophysically maximum production, also referred to as potential production, applies to theoretical conditions where only the defining factors define production. Feedlimited production applies to theoretical conditions where a combination of defining and limiting factors defines and limits production. The actual production realized on farms is the result of a combination of defining, limiting, and reducing factors. These factors are influenced by farmers through various management practices. The difference between potential and feedlimited production is explained by the limiting factors, and the difference between feed-limited production and actual production is explained by the reducing factors. The biophysical scope to increase production is the difference between the potential or feed-limited production and the actual production, which is the yield gap (van de Ven et al., 2003). Analysis of the yield gap can identify which of the biophysical factors contribute to the yield gap, and to what extent (van Ittersum et al., 2013). Based on yield gap analyses, tailored improvement options can be specified for mitigation of the most important factors contributing to yield gaps.

Unlike plant production, mechanistic modeling to conduct yield gap analyses is not widely used in livestock production systems, although some mechanistic livestock models are based on concepts similar to the concepts of production ecology (Emmans, 1988, 1997; Wellock et al., 2003). To our knowledge, only 2 mechanistic models are based on concepts of production ecology and use these concepts explicitly for simulating livestock growth and production as a function of the defining and limiting factors. The LIVSIM model was developed to simulate dairy cattle in smallholder systems in the Kenyan highlands (Rufino et al., 2009). This model does not account, however, for the defining factor climate and has yet not been used for yield gap analyses of dairy cows. The model LiGAPS-Beef (Livestock simulator for Generic analysis of Animal Production Systems - Beef cattle) was developed to simulate beef cattle in different beef production systems across the world (van der Linden et al., 2019a).

The objective of this study was therefore to develop and evaluate a mechanistic and generic dairy model that allows to analyze yield gaps in dairy production systems. We extended and adapted the model LiGAPSBeef for dairy cattle, and evaluated its performance for dairy production systems in the Netherlands with Holstein-Friesian cows. Finally, we quantified and analyzed yield gaps in milk production to illustrate the usefulness of the model.

\section{MATERIALS AND METHODS}

\section{Model Development}

A generic, mechanistic model for dairy cattle was developed from the model LiGAPS-Beef (van der Linden et al., 2019a,b,c). Its source code is written in the programming language $\mathrm{R}$ ( $\mathrm{R}$ Core Team, 2013) and is freely accessible (i.e., open source). The model LiGAPS-Beef consists of a thermoregulation submodel, a feed intake and digestion submodel, and an energy and protein utilization submodel (van der Linden et al., 2019a). These submodels jointly combine the effects of the genotype (i.e., cattle breed), climate, feed quality, and available feed quantity on the daily growth of an individual animal and calculate potential and feed-limited beef production for individual animals and for herds. Net energy (NE) and protein for growth are balancing variables in the model, because $\mathrm{NE}$ and protein requirements for metabolic processes other than growth, including lactation, have to be met first (van der Linden et al., 2019a). Milk production of beef cows in LiGAPS-Beef is only breed-dependent and independent of climate, feed quality, and available feed quantity. Hence, the model was not suited to simulate the potential and feed-limited milk production of dairy cows. We thus extended and adapted the model LiGAPS-Beef to a version for dairy cattle, and we named it LiGAPS-Dairy (Livestock simulator for Generic analysis of Animal Production Systems-Dairy cattle). The extensions and adaptations related to feed intake and milk production.

\section{Feed Intake}

Maximum feed intake capacity was expressed in fill units and described as a function of metabolic BW $\left(\mathrm{BW}^{0.75}\right)$. One fill unit corresponds to $1 \mathrm{~kg}$ of $\mathrm{DM}$ grass of standard quality, and fill units of other feeds are calculated relative to this standard (Jarrige et al., 1986). The relative increase in feed intake capacity during gestation $\left(\right.$ relFIC $_{\mathbf{G}}$ ) was assumed to be proportional to the increase in energy requirements for gestation compared with a similar, nongestating and nonlactating cow (Johnson et al., 2016). The relFIC ${ }_{G}$ was calculated from the $\mathrm{NE}$ requirements for maintenance $\left(\mathbf{N E}_{\mathbf{M}}\right)$, physical activity $\left(\mathbf{N E}_{\mathbf{P H A}}\right)$, and gestation $\left(\mathbf{N E}_{\mathbf{G}}\right)$ in LiGAPS-Dairy:

$$
\begin{gathered}
\operatorname{relFIC}_{\mathrm{G}}(\mathrm{t})=\left[\mathrm{NE}_{\mathrm{M}}(\mathrm{t})+\mathrm{NE}_{\mathrm{PHA}}(\mathrm{t})\right. \\
\left.+\mathrm{NE}_{\mathrm{G}}(\mathrm{t})\right] /\left[\mathrm{NE}_{\mathrm{M}}(\mathrm{t})+\mathrm{NE}_{\mathrm{PHA}}(\mathrm{t})\right]
\end{gathered}
$$


van der Linden et al.: MODELING YIELD GAPS IN DAIRY PRODUCTION

Maximum feed intake per $\mathrm{kg}$ of $\mathrm{BW}^{0.75}$ for dairy cows increases considerably after calving (Journet and Remond, 1976; Vandehaar and Black, 1991). The relative increase in maximum feed intake capacity $\left(\right.$ relFIC $\left._{\mathbf{L}}\right)$ during lactation was calculated according to Johnson et al. (2016). Default values were used to calculate relFIC $\mathrm{L}_{\mathrm{L}}$, except for the curvature parameter $\alpha$, which was established via model calibration. The maximum of either relFIC $\mathrm{G}_{\mathrm{G}}$ or relFIC $\mathrm{L}$ was used to calculate feed intake capacity:

$$
\begin{gathered}
\mathrm{FIC}(\mathrm{t})=\mathrm{BW}^{0.75}(\mathrm{t}) \times \mathrm{FIC}_{\mathrm{S}} \\
\times \max \left[\operatorname{relFIC}_{\mathrm{G}}(\mathrm{t}), \operatorname{relFIC}_{\mathrm{L}}(\mathrm{t})\right],
\end{gathered}
$$

where FIC is the feed intake capacity in fill units/ animal per day, and $\mathrm{FIC}_{\mathrm{S}}$ is the standard feed intake capacity (0.11 fill units/kg BW ${ }^{0.75}$ per day).

\section{Milk Production}

In LiGAPS-Dairy, the genetic potential for the shape of the lactation curve over time is described by Wood's equation (Wood, 1967). This genetic potential is only based on the animal's genetics, so the climate or other biophysical factors do not play a role. This equation expresses production in $\mathrm{kg}$ of milk/cow per day. Fat and protein concentrations of milk decrease after calving, down to a minimum, and then increase toward the end of the lactation. Average fat (Fat\%) and protein (Prot\%) concentration of Holstein-Friesian cows' milk throughout the lactation were adopted from Meijer et al. (1998). These concentrations were fitted to adapted Wood's equations by minimizing the root mean square error (RMSE) between measured percentages and percentages calculated from the adapted Wood's equations:

$$
\begin{aligned}
& \text { Fat\% }(\mathrm{t})=22.7-17.4 \times \mathrm{t}^{0.026} \times \mathrm{e}^{\left(-3.75 \times 10^{-3} \times \mathrm{t}\right)}, \\
& \operatorname{Prot} \%(\mathrm{t})=5.0-1.26 \times \mathrm{t}^{0.115} \times \mathrm{e}^{\left(-3.84 \times 10^{-3} \times \mathrm{t}\right)},
\end{aligned}
$$

where $\mathrm{t}$ indicates time in days after calving. Changes in lactose content $(4.5 \%)$ throughout lactation were assumed to be negligible. The gross energy in milk $\left(\mathbf{G E}_{\text {Milk }}, \mathrm{MJ} / \mathrm{kg}\right)$ throughout lactation was calculated from the gross energy contents of fat $(39.3 \mathrm{MJ} / \mathrm{kg})$, protein $(23.8 \mathrm{MJ} / \mathrm{kg})$, and lactose $(16.5 \mathrm{MJ} / \mathrm{kg})$, and the concentration of fat, protein and lactose in milk. The $\mathrm{GE}_{\text {Milk }}$ over the lactation was fitted to an adapted Wood's equation:

$$
\operatorname{GE}_{\text {Milk }}(\mathrm{t})=1.03 \times\left[5.50-1.79 \times \mathrm{t}^{0.103} \times \mathrm{e}^{\left(-1.73 \times 10^{-3} \times \mathrm{t}\right)}\right],
$$

where $\mathrm{t}$ indicates time in days after calving. Milk production was expressed also as fat- and protein-corrected milk (FPCM). An equation for FPCM was added to the model, using $4.0 \%$ fat content and $3.3 \%$ protein content as benchmarks (CVB, 2016). The gross energy in FPCM was $3.09 \mathrm{MJ} / \mathrm{kg}$. The calibration and evaluation of the model described in the next section were based on FPCM production to account for differences in milk composition.

First, energy and protein requirements for maintenance, physical activity, and gestation have to be met. If energy and protein from feed exceed these requirements, the remaining energy and protein are allocated to milk production and growth. The maximum amount of energy and protein allocated to milk production is determined by the genetic potential for milk production, which is described by the Woods equation. The 3 parameters of the Woods equation were fitted during model calibration, as described in the next section. The allocation between milk production and growth is dependent on the body condition of the animal and the lactation stage. Experimental results suggest a curvilinear relation between BCS and milk production, where especially low BCS is associated with reduced production (Roche et al., 2009; Pires et al., 2013). The BCS is correlated with the amount of subcutaneous fat tissue (Domecq et al., 1995). The subcutaneous and intermuscular fat tissue are both used as body reserves. In LiGAPS-Dairy, the weight of subcutaneous and intermuscular fat tissue is divided by the genetic maximum weight of subcutaneous and intermuscular fat tissue (FT) to reflect body condition. This genetic maximum weight is calculated the same way as in LiGAPS-Beef, where empirical equations were used to calculate the genetic maximum weight for bone, muscle and fat tissues in the carcass (van der Linden et al., 2019a). The reduction factor for the genetic potential milk yield (RFMY) is written as a function of FT, which resembles the curvilinear relation between BCS and milk production reported in literature. Hence, the RFMY allows cows with lower BCS to allocate less energy and protein to milk production and more to growth:

$$
\operatorname{RFMY}(\mathrm{t})=\min \left[1, \mathrm{FT}^{0.5}(\mathrm{t})+\mathrm{RFMY}_{\min }\right],
$$

where $\mathrm{RFMY}_{\min }$ is the minimum value for RFMY, based on experimental data. Allocation between milk production and growth is also dependent on the stage 
of lactation. Priority is given to milk production in early lactation, which results in mobilization of fat tissues and subsequent loss of body weight. Priority is gradually shifted to growth during later phases of lactation to regain body (fat) tissues. A scaling factor for body growth during lactation $\left(\mathbf{S F}_{\mathbf{G}}\right)$ was adopted from Johnson et al. (2016). This factor is negative in early lactation and positive during later stages in lactation. Cows are assumed to be able to mobilize fat tissues up to d 95 after calving if energy deficiencies occur.

$$
\mathrm{SF}_{\mathrm{G}}(\mathrm{t})=(\mathrm{t}-95) /(\mathrm{t}+95),
$$

where $\mathrm{t}$ is the time in days after calving. Up to d 95 after calving, the NE available for lactation $\left(\mathbf{N E}_{\mathbf{L}}\right)$ is described as a function of RFMY, $\mathrm{SF}_{\mathrm{G}}$, and the remaining NE not used for maintenance, physical activity, and gestation $\left(N E_{R}\right)$. After d 95 , a fraction of the energy is allocated to growth if the weight of the subcutaneous and intermuscular fat tissue is below the genetic maximum.

$$
\begin{aligned}
\mathrm{NE}_{\mathrm{L}}\left(\mathrm{t}_{\leq 95}\right)= & \min \left\{\mathrm{NE}_{\text {Lgenotype }}(\mathrm{t}) \times \operatorname{RFMY}(\mathrm{t}), \mathrm{NE}_{\mathrm{R}}(\mathrm{t})\right. \\
& \left.\times\left[1+\mathrm{MF} 1 \times\left|\mathrm{SF}_{\mathrm{G}}(\mathrm{t})\right|\right]\right\}
\end{aligned}
$$

$$
\begin{aligned}
& \mathrm{NE}_{\mathrm{L}}\left(\mathrm{t}_{>95}\right)=\min \left(\mathrm{NE}_{\text {Lgenotype }}(\mathrm{t}) \times \operatorname{RFMY}(\mathrm{t}), \mathrm{NE}_{\mathrm{R}}(\mathrm{t})\right. \\
& \left.\quad \times\left\{1-\operatorname{MF} 2 \times\left|\mathrm{SF}_{\mathrm{G}}(\mathrm{t})\right| \times[1-\mathrm{FT}(\mathrm{t})]\right\}\right), \quad[9]
\end{aligned}
$$

where $\mathrm{t}$ is time in days after calving, $N E_{\text {Lgenotype }}$ is the $\mathrm{NE}$ required to produce the genetic maximum milk yield, and MF1 and MF2 are multiplication factors for $\mathrm{SF}_{\mathrm{G}}$, based on experimental data. After calculation of $N E_{L}$, the NE for growth is the balancing variable. Growth is negative if $\mathrm{NE}_{\mathrm{L}}$ is larger than $\mathrm{NE}_{\mathrm{R}}$, which means that body reserves are mobilized. It is assumed that $75 \%$ of the mobilized body reserves are from subcutaneous and intermuscular fat in the carcass (gross energy: 29.6 $\mathrm{MJ} / \mathrm{kg}$, conversion efficiency from gross energy to NE assumed to be $90 \%$ ), and $25 \%$ from noncarcass tissues (gross energy $/ \mathrm{kg}$ tissue varies over time in LiGAPSDairy, conversion efficiency from gross energy to NE assumed to be $90 \%$ ). The milk yield is calculated from $\mathrm{NE}_{\mathrm{L}}$ on a daily basis. Protein required for lactation $\left(\mathbf{P r o t}_{\mathbf{L}}\right)$ is calculated from the milk yield (MY, kg/ cow per day), Prot\%, and the conversion efficiency of metabolizable protein to milk protein $\left(\eta_{\text {prot }}\right.$; CSIRO, 2007).

$$
\operatorname{Prot}_{L}(t)=M Y(t) \times \operatorname{Prot} \%(t) / \eta_{\text {prot }}
$$

For simplicity, it is assumed that protein deficiency decreases milk yields, but not the protein concentration of the milk (Sutton, 1989). Similar to NE, the protein requirements for maintenance, physical activity, and gestation have to be met first. The remaining protein is allocated to milk production and growth. Protein deficiency occurs if the amount of protein allocated to milk production is lower than $\operatorname{Prot}_{\mathrm{L}}$. If so, the milk production under protein deficiency is reduced proportionally to the amount of protein available for lactation relative to $\operatorname{Prot}_{\mathrm{L}}$. Hence, daily MY can be limited by both energy and protein deficiency. Protein deficiency in nonlactating cows results in a reduction in growth, as described by van der Linden et al. (2019a). Excess protein in the diet was assumed not to reduce milk production and growth. In LiGAPS-Dairy, excess protein increases nitrogen excretion via urine and decreases the nitrogen use efficiency.

\section{Calibration and Evaluation}

Experimental Data. Model evaluation is essential before its application to justify the model can be used for the purpose it has been developed for. The accuracy of model results is quantified during such an evaluation by comparing model results with independently measured experimental data (Bellocchi et al., 2010). We compared results of LiGAPS-Dairy with data from 2 experimental farms with Holstein-Friesian cows in the Netherlands, which were part of a larger data set of Wageningen Livestock Research, Wageningen University, the Netherlands (Zom et al., 2012b). Data were obtained from 1 experiment at experimental farm 't Gen and 2 experiments at the experimental farm De Waiboerhoeve. Both farms were located near Lelystad $\left(52.5^{\circ} \mathrm{N}, 5.6^{\circ} \mathrm{E}\right)$, the Netherlands. The average annual temperature on this location is $10.1^{\circ} \mathrm{C}$ and the average precipitation is $826 \mathrm{~mm} / \mathrm{yr}$ (1992-2018). The experiment conducted at 't Gen lasted from October 1991 to January 1995 (Zom et al., 2012b). The experiments at De Waiboerhoeve lasted from 1993 to April 1997 (Meijer et al., 1998; van Duinkerken et al., 2005). Only cows with more than $30 \mathrm{wk}$ of data recordings were selected for model calibration and evaluation. This criterion was met by 220 cows [ 77 at 't Gen, 76 from the experiment of Meijer et al. (1998), and 67 from the experiment of van Duinkerken et al. (2005)]. They had 349 lactations, and more than 11,000 weekly aggregated milk production measurements.

Holstein-Friesian cows were permanently kept in cubicle sheds and milked twice a day in all experiments. They were fed with fresh grass, grass silage, hay, straw, maize silage, and concentrates. Drinking water and feed (except for concentrates) were available ad libitum. Feed quality (including DM content, CP content, and digestibility) and milk quality (fat and protein content) 
were measured weekly. Individual feed intake and milk yields were measured on a daily basis, and were aggregated per week (Zom et al., 2012b). First, aggregation was conducted because feed and milk quality were measured weekly. Second, aggregation reduces large day-to-day variation in feed intake due to meals just before or after the time that separates a 24 -h period from another. Third, aggregation reduces day-to-day variation because it accounts for transfer of a part of the concentrates budget to the next 24 -h period when a cow does not fully consume the concentrate allowance in the current 24-h period. Aggregation per week is a regular procedure that is described in documents for internal procedures of Wageningen Livestock Research (Ronald Zom, personal communication).

All weekly data were interpolated and expressed as daily data, because the time step of LiGAPS-Dairy is 1 d. Average daily milk production in the 3 experiments was 28 to $30 \mathrm{~kg}$ of FPCM. The average milk fat content was $4.42 \%$, and the average milk protein content was $3.57 \%$. The average digestibility of the diet was $70.6 \%$, which is equivalent to $10.7 \mathrm{MJ}$ of $\mathrm{ME} / \mathrm{kg}$ of DM. The average $\mathrm{CP}$ content was $168 \mathrm{~g}$ of $\mathrm{CP} / \mathrm{kg}$ of $\mathrm{DM}$. Individual body weights were measured at least once per week.

Model Inputs and Settings. Information about the genetic makeup of individual animals was not available. Therefore, it was assumed that the genetic potential for milk production and other genetic characteristics were similar for all cows. Similar to LiGAPSBeef, LiGAPS-Dairy uses 22 parameters describing the animal's genotype. As presented in Supplemental Table S1 (http://dx.doi.org/10.17632/kndd25m5y3.1, van der Linden, 2021), 16 parameters were specific for the Holstein-Friesian breed, 5 parameters were assumed to be universal for Bos taurus cattle, and a parameter for the lipid concentration in bones of Holstein-Friesian cows was assumed to be the same as the parameter for beef breeds of similar weight. The average rumen content for Holstein-Friesian cattle was assumed to be $20 \%$ of the total BW (NRC, 2001; Yan et al., 2009), which was higher than the percentage in LiGAPS-Beef. The fraction of bones in the carcass of dairy cows was higher than for beef cows. The parameter determining bone growth was adjusted to that reported in literature (Lawrence et al., 2010).

Required weather variables were the same as the ones required for LiGAPS-Beef (van der Linden et al., 2019a). Daily weather data for the experimental farms were obtained from a nearby weather station in Lelystad $\left(52.5^{\circ} \mathrm{N}, 5.5^{\circ} \mathrm{E}\right.$, altitude $-4 \mathrm{~m}$ above sea level) (KNMI, 2019). Outside temperatures were assumed to be equal to indoor temperatures and solar radiation was assumed to be zero, because the roof of the stable was nontranslucent.

Under potential conditions, feed quality and available feed quantity are not limiting production (van de Ven et al., 2003). Therefore, the diet for potential production must maximize feed digestibility, $\mathrm{ME}$ and $\mathrm{CP}$ content, and also contain sufficient physically effective NDF to sustain rumen functioning (van der Linden et al., 2015, 2019a). The CP content was set at $225 \mathrm{~g} / \mathrm{kg}$ of DM to avoid protein deficiency and the physically effective NDF was set at $210 \mathrm{~g} / \mathrm{kg}$ of DM to sustain rumen functioning (Mertens, 1997). The ME content was maximized (i.e., as high as possible) using linear programming, which is also referred to as linear optimization. Ingredients of the diet were soybean meal for CP supply, wheat grain for ME supply, and good quality hay for supply of physically effective NDF. The theoretical diet that met the requirements consisted of $19.5 \%$ soybean meal, $31.8 \%$ wheat, and $48.6 \%$ good quality hay. The ME content of this diet was $13.5 \mathrm{MJ} /$ $\mathrm{kg}$ of DM, the NDF content was $318 \mathrm{~g} / \mathrm{kg}$ of DM, and 1 $\mathrm{kg}$ of DM equals 0.80 fill units. This diet was assumed to be fed ad libitum before and during the experiments under potential production. Under feed quality limited conditions, diets correspond to the diets fed on-farm during the experiments. The measured feed quality (ME and CP content) over time was used as model input. Because cows had ad libitum access to feed in the experimental farms, we assumed that feed quantity was not limiting milk production.

Cow health was regularly checked at the experimental farms. For calibration and evaluation, only data of clinically healthy cows were used from the experiments at the Waiboerhoeve (Zom et al., 2012a,b). Therefore, effects of the reducing factors stress and diseases on milk production were assumed to be negligible. Because feed quantity limitation and reducing factors were assumed absent, the actual milk production $\left(\mathbf{Y}_{\mathbf{A}}\right)$ on the experimental farms is expected to approximate the feed quality limited milk production $\left(\mathbf{Y}_{\mathbf{L}}\right)$. This implies also that the yield gap in the experiments is approximately the difference between potential milk production $\left(\mathbf{Y}_{\mathbf{P}}\right)$ and $\mathrm{Y}_{\mathrm{L}}$.

Individual cows were simulated from birth up to the end of the experimental periods. Birth dates or ages of cattle were not available for most cows, but cattle weights were available. We assumed that cows below $383 \mathrm{~kg}$ were primiparous cows of $2 \mathrm{yr}$ old, cows between 383 and $554 \mathrm{~kg}$ were $3 \mathrm{yr}$ old, and cows above $554 \mathrm{~kg}$ were $4 \mathrm{yr}$ old. The feed available before the experiment was adjusted in such a way that the simulated weight under feed quality limited production corresponded to the measured weight at the start of an experiment. 
Methods for Calibration and Evaluation. The model LiGAPS-Dairy was calibrated and evaluated by K-fold cross-validation, which is sometimes referred to as cross-partitioning. This method splits the total experimental data into parts of a similar size. All parts minus 1 are used for model calibration, and 1 part for model evaluation (Hastie et al., 2009). A major advantage of K-fold cross-validation over the single-split method is the more robust assessment of a model's performance, because all data are used for both calibration and evaluation instead of random data selection for either calibration or evaluation. In addition, the method allows to estimate the uncertainty around a model's performance (Peterson et al., 2011).

Experimental data were split in 3 parts, each part corresponding to 1 experiment. Hence, data of each experiment were used twice for model calibration and once for model evaluation during K-fold cross-validation. LiGAPS-Dairy was calibrated by improving the fit between the simulated milk production and feed intake per lactation under feed quality limited production and the measured milk production and feed intake per lactation, because the model is primarily developed to simulate milk production levels and feed efficiency. Milk yield was expressed in $\mathrm{kg}$ of FPCM per lactation. Several lactating cows were excluded from experiments by the personnel of the experimental farms. As a result, a minority of lactations was incomplete (i.e., no full lactation). This was irrelevant for the present study, because measured and simulated milk production up to exclusion (at least $30 \mathrm{wk} /$ animal) were considered to be adequate for model evaluation. During model calibration the difference between simulated and measured milk production per lactation was minimized, as well as the difference between simulated and measured feed intake per lactation. Differences in milk production and feed intake were both expressed as RMSE (Bennett et al., 2013). All Holstein-Friesian cows were assumed to have the same genotype (i.e., no variation in the genetic parameters), so LiGAPS-Dairy was calibrated for the average genotype of cows. The following 8 parameters were manually adjusted to minimize the average of both RMSE: the 3 parameters of Wood's equation (Wood, 1967), the conversion efficiency of ME to NE for lactation, and the conversion efficiency of metabolizable protein to milk protein $\left(\eta_{\text {prot }}\right)$ were calibrated because these parameters are expected to affect the milk production of dairy cows to a large extent. Parameters $\mathrm{RFMY}_{\text {min }}$ (Equation 6), MF1 (Equation 8) and the curvature parameter $\alpha$ for maximum feed intake (Johnson et al., 2016) were calibrated because they were new to the model and play a major role in the allocation of energy and protein to milk and growth of body tissues
(Supplemental Table S2, http://dx.doi.org/10.17632/ kndd25m5y3.1, van der Linden, 2021). Adjusting NE requirements for maintenance and conversion of digestible to metabolizable energy, 2 parameters to which LiGAPS-Beef was sensitive (van der Linden et al., 2019b), did not further reduce the RMSE. Parameter MF2 (Equation 9) was set to 2.0, and adjusting this value did not further reduce the RMSE either.

The average performance of LiGAPS-Dairy under calibration and evaluation using $\mathrm{K}$-fold cross-validation was calculated according to Hastie et al. (2009). The difference between simulated and measured milk yields was expressed as the mean absolute error (MAE), relative MAE, mean square error (MSE), RMSE, and relative RMSE (Bennett et al., 2013). The MSE was further split in the bias, slope, and random component (Bibby and Toutenburg, 1977). This approach allows to investigate what part of the MSE could be attributed to systematic errors (bias component), inability to resemble the variability in milk production (slope component), and unexplained variance (random component). Furthermore, linear regression was used to investigate whether simulated and measured milk production and feed intake differed significantly from each other.

Model Illustration. The model LiGAPS-Dairy was developed to simulate $Y_{P}$ and $Y_{L}$ of dairy cows, which allows to quantify and analyze yield gaps. Yield gaps of Holstein-Friesian cows were calculated as the difference between the simulated $Y_{P}$ and $Y_{A}$ ( $k g$ of FPCM per lactation). Model illustration was conducted with the averages of the 8 parameters that were adjusted during the calibration procedure. Similarly to yield gaps, productivity gaps were calculated as the difference in feed efficiency under potential production and actual production ( $\mathrm{kg}$ of FPCM $/ \mathrm{kg}$ of DM feed intake). Similar to LiGAPS-Beef, the model LiGAPS-Dairy lists the factors that define or limit production most. The defining factor climate was split into heat stress and cold stress. Heat stress occurs if heat production from all metabolic processes exceeds the maximum heat release of the animal in the ambient climate. Under heat stress, feed intake is reduced to the level that heat production equals maximum heat release. Milk production and growth are thus defined by the occurrence of heat stress. Cold stress occurs if heat production is below the minimum heat release of the animal, and results in an increase in feed intake if sufficient feed is available. The limiting factor feed quality was split into feed intake capacity limitation (animal cannot consume more fill units) and protein deficiency (van der Linden et al., 2019a). Simulated body weights of cows corresponded to the measured weights at the start of an experiment under feed quality limited production. This was achieved by 
van der Linden et al.: MODELING YIELD GAPS IN DAIRY PRODUCTION

Table 1. Calibration of LiGAPS-Dairy for data of 3 experiments with a total of 220 Holstein-Friesian cows in the Netherlands ${ }^{1}$

\begin{tabular}{|c|c|c|c|c|c|}
\hline Calibration statistics $^{2}$ & Units $^{3}$ & $\begin{array}{c}\text { Milk yield } \\
\text { per lactation }\end{array}$ & $\begin{array}{c}\text { Daily } \\
\text { milk yield }^{5}\end{array}$ & $\begin{array}{l}\text { Feed intake } \\
\text { per lactation }\end{array}$ & $\begin{array}{c}\text { Daily } \\
\text { feed intake }\end{array}$ \\
\hline Average measured & $\mathrm{kg}$ of $\mathrm{FPCM}$ or $\mathrm{kg}$ of $\mathrm{DM}$ & $8,516(348)$ & $29.6(0.4)$ & $6,063(227)$ & $20.5(0.1)$ \\
\hline Average simulated & $\mathrm{kg}$ of $\mathrm{FPCM}$ or $\mathrm{kg}$ of $\mathrm{DM}$ & $8,427(407)$ & $29.5(0.5)$ & $6,220(307)$ & $21.1(0.3)$ \\
\hline Mean absolute error & $\mathrm{kg}$ of $\mathrm{FPCM}$ or $\mathrm{kg}$ of $\mathrm{DM}$ & $974(21)$ & $5.0(0.4)$ & $607(72)$ & $3.3(0.4)$ \\
\hline Relative mean absolute error & $\%$ & $11.5(0.5)$ & $18.1(1.6)$ & $10.0(0.8)$ & $18.8(2.4)$ \\
\hline Root mean square error & $\mathrm{kg}$ of $\mathrm{FPCM}$ or $\mathrm{kg}$ of $\mathrm{DM}$ & $1,250(34)$ & $6.5(0.7)$ & $786(83)$ & $4.0(0.4)$ \\
\hline Slope component & $\% \mathrm{MSE}$ & $4.4(4.1)$ & $15.1(1.8)$ & $2.5(1.2)$ & $27.1(3.5)$ \\
\hline Random component & $\% \mathrm{MSE}$ & $94.6(3.7)$ & $51.2(6.1)$ & $91.2(2.7)$ & $41.6(3.9)$ \\
\hline$P$-value intercept equal to 0 & - & $0.278(0.147)$ & $0.085(0.025)$ & $0.177(0.163)$ & $0.015(0.006)$ \\
\hline$P$-value slope equal to 1 & - & $<0.001$ & $0.013(0.004)$ & $<0.001$ & $0.040(0.016)$ \\
\hline
\end{tabular}

${ }^{1}$ Values between brackets indicate SE.

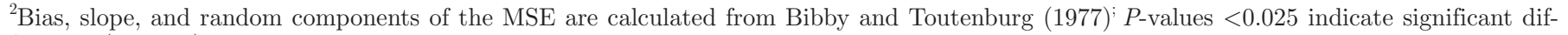
ferences (2-tailed).

${ }^{3} \mathrm{FPCM}=$ fat- and protein-corrected milk; MSE = mean square error.

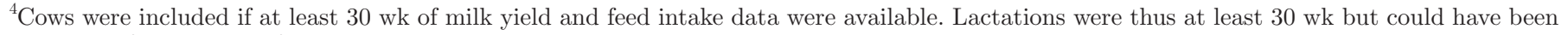
extended after the end of experiments.

${ }^{5}$ Daily milk yields and feed intake are based on interpolated weekly data.

adjusting the model input feed availability before the start of an experiment. Cows simulated under potential production were fed ad libitum before the start of an experiment, because feed availability does not play a role under potential production. As a result, simulated body weights under potential production were higher than simulated body weights under feed quality limited production at the start of experiments. The model LiGAPS-Dairy allocates a higher percentage of energy and protein to milk production and a lower percentage to body reserves at higher body weights. One of the reasons why simulated milk production during experimental periods is higher under potential production than under feed quality limited production is thus related to higher initial weights. The yield gap in milk production is thus partially explained by differences in initial weight. The factor initial weight, therefore, was taken into account in yield gap analysis.

The factors listed were the primary factors that define and limit milk production. For example, if a reduced feed intake due to heat stress resulted in energy or protein deficiency, heat stress was considered the primary factor that determined milk production. The factors for milk production identified with LiGAPS-Dairy were subsequently compared with the factors provided in the literature to analyze and explain yield gaps. In addition to the yield gap, the difference between the genetic potential for milk production (described by the shape of Wood's equation) and $Y_{P}$ was analyzed. This difference is explained by the defining factor climate, which was split into heat stress and cold stress.

\section{RESULTS AND DISCUSSION}

\section{Calibration and Evaluation}

Calibration. The model was calibrated 3 times, with different combinations of data from 2 experiments each time. The average MAE per cow was $974 \mathrm{~kg}$ of FPCM per lactation, which corresponds to $11.5 \%$ of the FPCM production (Table 1). The average RMSE per lactation was $1,250 \mathrm{~kg}$ of $\mathrm{FPCM}$, equivalent to $14.8 \%$ of the FPCM production. In comparison, the relative RMSE ranged between 7 and $17 \%$ after calibration of the model LIVSIM for Holstein $\times$ Boran cows in Ethiopia (Rufino et al., 2009). Hence, the accuracy of LiGAPS-Dairy is within the range reported by Rufino et al. (2009).

The relative MAE and relative RMSE were higher for daily MY (interpolated from weekly data) than for average MY per lactation (Table 1). This is explained by the occurrence of both overestimation and underestimation of daily simulated milk production, which average out when the milk production per lactation is calculated. In addition, a minor explanation may be the use of daily milk production that was based on interpolation from measured weekly data, whereas daily milk production was simulated. The relative MAE and relative RMSE for feed intake per lactation and per day were similar to those of MY (Table 1).

After calibration, the bias component of the MSE for MY per lactation was $1.0 \%$ and slope component was $4.4 \%$ (Table 1). The calibrated model thus reproduced 
van der Linden et al.: MODELING YIELD GAPS IN DAIRY PRODUCTION

the variability of measured milk yields closely with little bias, which indicates the model was calibrated adequately (Figure 1). The random component of the MSE and the MAE and RMSE may be partially explained by the use of generic parameters that reflect the assumed average genotype of a Holstein-Friesian cow in the experiments. Individual genotypes differed, however, from the average genotype, thereby causing differences between measured and simulated milk yields. In addition, the genetic potential for milk production of Holstein-Friesian cows is known to have increased gradually over time due to breeding (Veerkamp et al., 2013), which may have changed the genotype over the years in which the 3 experiments were conducted. Accounting for variation in animals and animal genetics may further improve the fit between simulated and measured milk yields (Tedeschi et al., 2014).

For milk yields per lactation the average intercept of the regression line between simulated and measured yields was not significantly different from 0 , but the average slope was significantly different from $1(P<$ 0.001; Table 1). These metrics indicate that simulated and measured milk yields per lactation differed significantly. For the daily milk yields likewise the intercept of the regression line between simulated and measured yields was not significantly different from 0 , but the slope was significantly different from $1(P=0.013$; Table 1).

Model Evaluation. The MAE for milk production per lactation was $1,034 \mathrm{~kg}$ of FPCM per cow per lactation, which was equivalent to $12.2 \%(\mathrm{SE}=0.9 \%)$ of the measured production (Figure 2, Table 2). The relative MAE for daily milk yields was $18.7 \%$. The relative RMSE for milk production per lactation was $15.5 \%$, and the relative RMSE for daily milk yields was $22.7 \%$ (Table 2). These values broadly correspond to RMSEs reported for dairy models. The Cornell-PennMiner Dairy model, for example, had a relative RMSE of $15.9 \%$ of the observed postpeak daily milk yields (Tedeschi et al., 2008). A comparison study of 4 dairy models indicated that relative RMSEs ranged between 20 and $31 \%$ of the observed daily milk yields (Tedeschi et al., 2014). These model performances are not directly comparable to the performance of LiGAPS-Dairy, because Tedeschi et al. (2008 and 2014) used data for multiple countries to evaluate milk yields, whereas this study focused on the Netherlands only. In addition, the dairy models in the studies of Tedeschi et al. (2008, 2014) used feed intake as an input, whereas feed intake is a model output of LiGAPS-Dairy under ad libitum feed supply.

For milk production per lactation the bias component of the MSE was relatively large ( $31 \%$ of MSE). This is mainly due to the experiment described in Meijer et
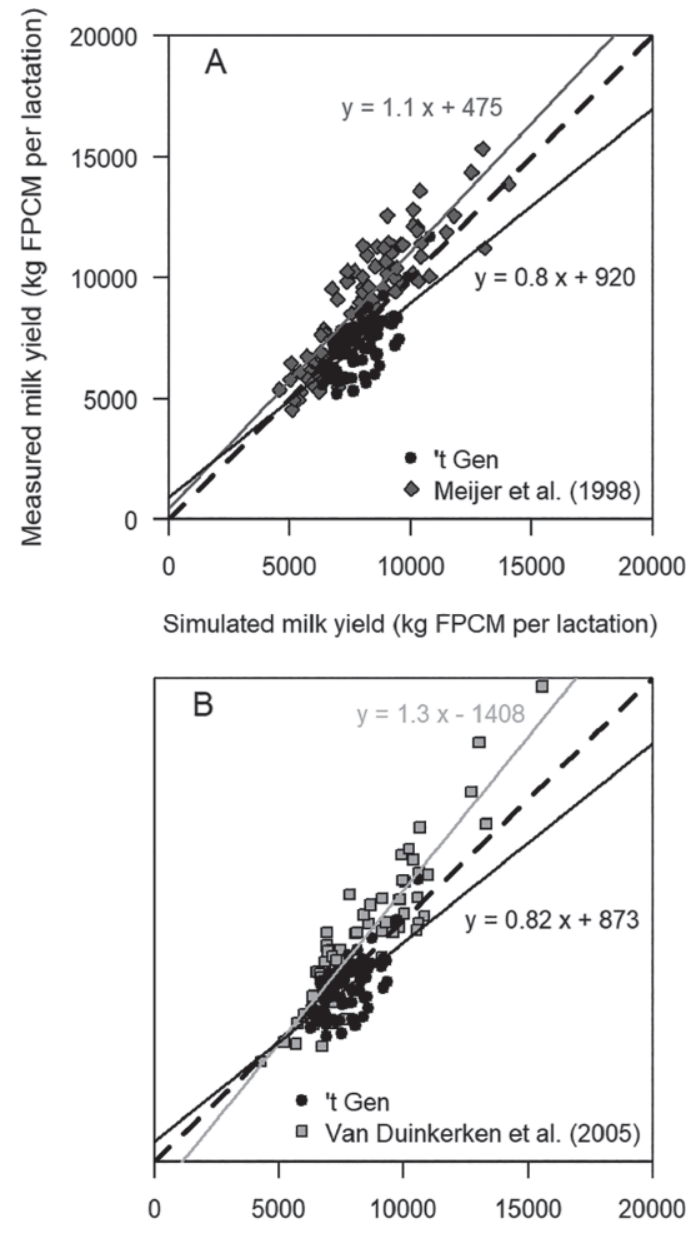

Simulated milk yield (kg FPCM per lactation)

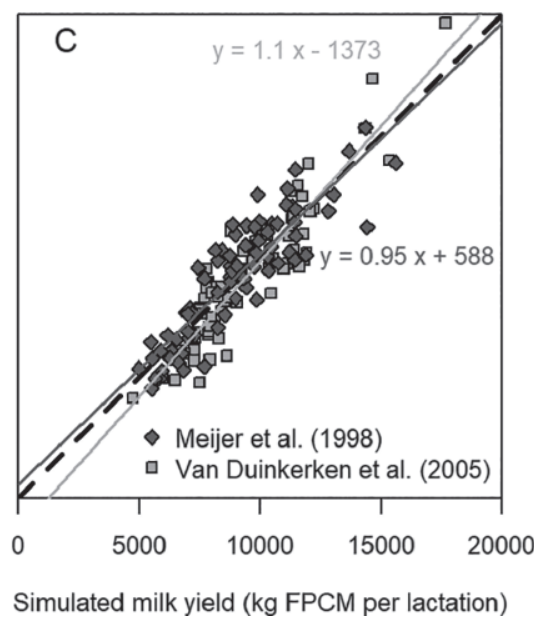

Figure 1. Simulated and measured milk production of HolsteinFriesian cows in 3 experiments after model calibration. One experiment was conducted at experimental farm 't Gen. Experiments described by Meijer et al. (1998) and van Duinkerken et al. (2005) were conducted at experimental farm De Waiboerhoeve. Data of 2 experiments were used at a time for calibration in 3 different combinations $(\mathrm{A}-\mathrm{C})$. Dashed lines indicate 1:1 lines; solid lines indicate regression lines of individual experiments. FPCM $=$ fat- and protein-corrected milk. 
van der Linden et al.: MODELING YIELD GAPS IN DAIRY PRODUCTION

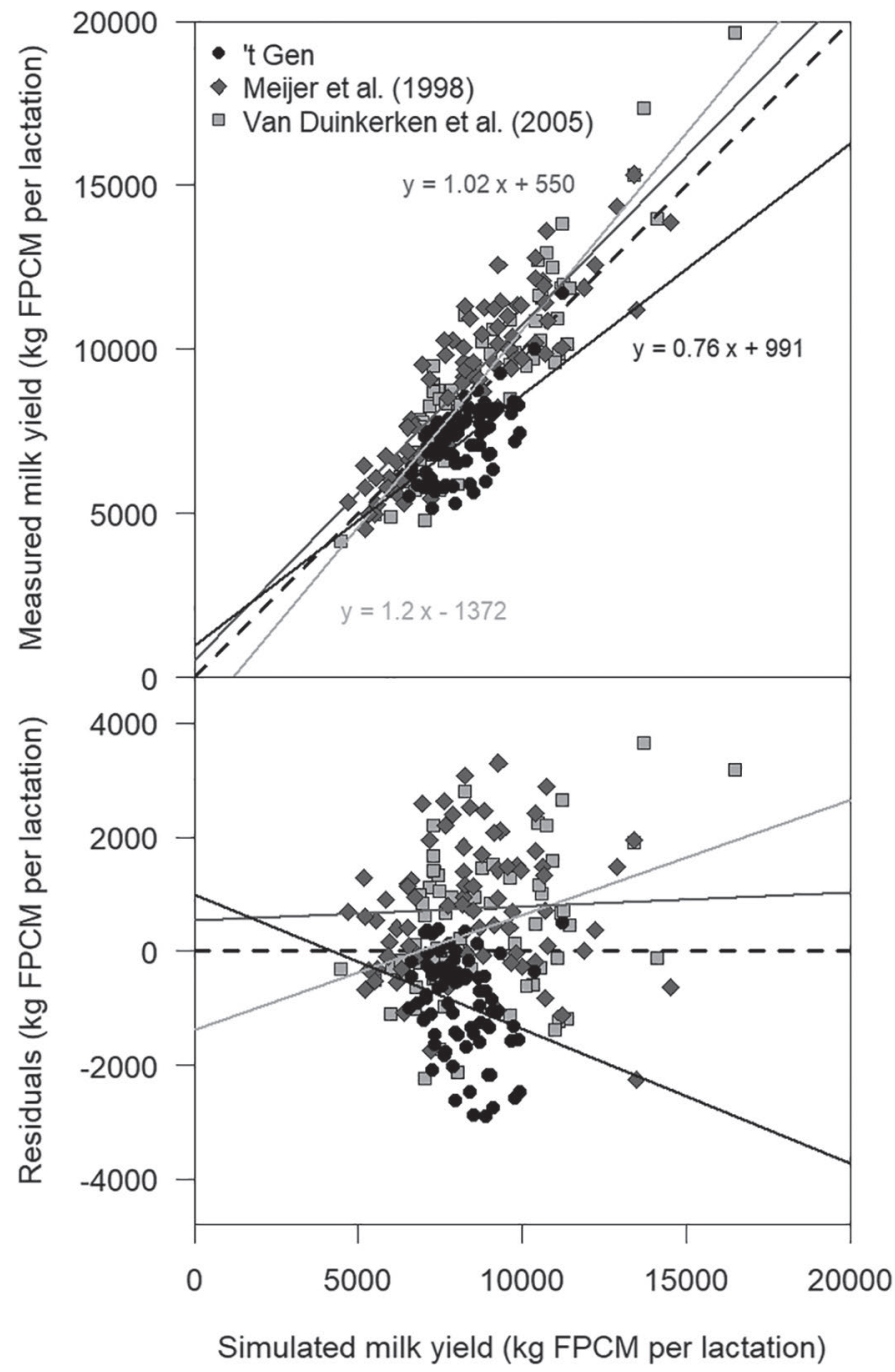

Figure 2. Simulated and measured milk yields of Holstein-Friesian cattle in 3 experiments under model evaluation. Dashed lines indicate 1:1 lines. Solid lines indicate regression lines, and their colors correspond to the colors of the experiments. FPCM = fat- and proteincorrected milk.

al. (1998), where measured milk yields per lactation were higher than simulated milk yields and where the majority of the MSE was explained by bias (55\% for milk production per lactation). This experiment had the highest milk production per lactation. Model users should thus pay attention to the parameters related to the genotype, in particular Wood's equation that describes the genetic potential for the shape of the lactation curve over time.

For milk production per lactation the average intercept of the regression line between simulated and measured yields was not significantly different from 0 $(P=0.191)$, but the average slope was significantly different from $1(P<0.001$; Figure 2, Table 2). Similar results were found for the daily milk yields, which in- dicates that there was a significant difference between simulated and measured values.

The MAE for simulated feed intake per lactation was $627 \mathrm{~kg}$ of DM per cow per lactation, which was equivalent to $10.3 \%$ of the average measured feed intake (Figure 3, Table 2). Feed intake per lactation was overestimated on average by $157 \mathrm{~kg}$ of DM, or $2.6 \%$ by the model (Table 2). The performance of LiGAPS-Dairy for feed intake corresponded with its performance for milk production, where relative MAE and RMSE were similar. The average measured feed efficiency was 1.41 $\mathrm{kg}$ of $\mathrm{FPCM} / \mathrm{kg}$ of DM feed intake, and the simulated feed efficiency was $1.36 \mathrm{~kg}$ of $\mathrm{FPCM} / \mathrm{kg}$ of DM feed intake, which is a difference of $3.5 \%$. Whether the values of the metrics used to evaluate the performance of a model are acceptable depends on the purposes the model was designed for and the specific interests of the model user (Bellocchi et al., 2010). We think the current performance of LiGAPS-Dairy is acceptable for Holstein-Friesian cattle in the Netherlands, especially if one focuses on milk yield and feed intake per lactation. Model users should be careful to use LiGAPS-Dairy for simulating day-to-day variation in milk yields and feed intake, because of the relatively high RMSE.

\section{Model Illustration}

Yield Gaps. Application of LiGAPS-Dairy indicated that the average $Y_{P}$ was $9,549 \mathrm{~kg}$ of FPCM per lactation (Table 3 ). The corresponding average yield gap was 1,009 $\mathrm{kg}$ of FPCM per lactation, equivalent to $10.6 \%$ of $Y_{P}$, or complementary, $Y_{A}$ was $89.4 \%$ of $Y_{P}$. In crop production, farmers' yields generally plateau at 75 to $85 \%$ of the limited or potential production, due to risk aversion and diminishing returns on inputs and environmental effect (Cassman et al., 2003; van Ittersum et al., 2013). In this study on dairy cows, $\mathrm{Y}_{\mathrm{A}}$ was above 75 to $85 \%$ of $\mathrm{Y}_{\mathrm{P}}$, which may not be surprising given the experimental context and the inclusion of data for clinically healthy cows only.

The yield gap expressed as feed efficiency (i.e., productivity gap) was on average $0.23 \mathrm{~kg}$ of $\mathrm{FPCM} / \mathrm{kg}$ of DM, which was $14.2 \%$ of the average potential feed efficiency (Table 3). The productivity gaps were in line with relative lactation yield gaps. However, the model tended to overestimate feed intake (Table 2), which reduced the simulated feed efficiency.

Yield Gap Analysis. Yield gap analysis entails identification of the biophysical factors that define, limit or reduce agricultural production (van Ittersum et al., 2013). Following our assumptions that reducing factors were absent (only clinically healthy cows) and that feed quantity limitation was absent too (ad libitum diets), the yield gap was approximately the difference 
between $Y_{\mathrm{P}}$ and $\mathrm{Y}_{\mathrm{L}}$. Given the concepts of production ecology, $Y_{\mathrm{P}}$ is defined by the genotype of the animal and the climate (van de Ven et al., 2003). The difference between the genetic potential of the cows $(9,586$ $\mathrm{kg}$ of FPCM per lactation) and $\mathrm{Y}_{\mathrm{P}}$ is $37 \mathrm{~kg}$ of FPCM per lactation (Figure 4). This difference is explained by heat stress $(0.4 \mathrm{~kg}$ of FPCM), cold stress $(23 \mathrm{~kg}$ of FPCM), and feed intake capacity (13 kg of FPCM). Hence, feed intake capacity could not be fully eliminated under potential production, despite the design of the optimal diet to fully eliminate the limiting factors. This result closely matches results for LiGAPS-Beef, where feed intake capacity also played a minor role under potential production (van der Linden et al., 2019a).

The approximate yield gap, defined as the difference between $Y_{P}$ and $Y_{L}(1,083 \mathrm{~kg}$ of FPCM per lactation) is mainly explained by protein deficiency $(39.4 \%, 427$ $\mathrm{kg}$ of FPCM per lactation), the initial weight of the animals at the start of experiments $(36.5 \%, 395 \mathrm{~kg}$ of FPCM per lactation), feed intake capacity $(23.5 \%, 254$ $\mathrm{kg}$ of FPCM per lactation) and heat stress $(1.2 \%, 13 \mathrm{~kg}$ of FPCM per lactation; Figure 4). The initial weights of cows in experiments corresponded to the measured weights under feed quality limited production, but not under potential production. Cow weights at the start of experiments were lower under feed quality limited production than under potential production, and as a result more energy and protein were allocated to growth to regain body tissues instead of milk production under feed quality limitation. Andre et al. (2011) estimated average milk losses due to heat stress to be $31.4 \mathrm{~kg} /$ cow per year in the Netherlands, which corresponded to a reduction of $0.32 \%$ in milk production. In addition, milk losses related to heat stress were estimated to be
$62 \mathrm{~kg} / \mathrm{cow}$ on an average Dutch farm (Timmerman et al., 2018). Hence, the simulated milk loss due to heat stress was lower than the reported values in the literature. Heat stress is a defining factor of which the effect is aggravated under feed quality limited production due to a higher heat increment of feeding of the diet (Figure 4). The reverse holds for cold stress, which explains why this factor decreased the yield gap between $Y_{P}$ and $\mathrm{Y}_{\mathrm{L}}(-0.6 \%,-7 \mathrm{~kg}$ of FPCM per lactation).

The model LiGAPS-Dairy identified when particular biophysical factors define and limit milk production. Because $Y_{L}$ was assumed to approximate $Y_{A}$, the occurrence of factors that define and limit $Y_{L}$ are assumed to resemble practice most. Figure 5 presents these factors for the first $210 \mathrm{~d}$ after calving. Milk production was defined by the genotype on average for $53 \%$ of the total time cows were kept in the experiments. The genotype mainly defined milk production beyond $35 \mathrm{~d}$ after calving (Figure 5).

Heat stress defined production on average during $1 \%$ of the experimental time. Heat stress mostly occurred at maximum daily temperatures above $14^{\circ} \mathrm{C}$ (Figure 6A). This result corresponds to Andre et al. (2011) who indicated that heat stress is expected above the upper critical temperature of $17.8^{\circ} \mathrm{C}$ for HolsteinFriesian cows in the Netherlands. Some maximum daily temperatures at which heat stress occurred, although only occasionally, were below $14^{\circ} \mathrm{C}$ (Figure 6A). This may be explained by a combination of high milk yields and environmental conditions restricting heat release (high solar radiation levels, low wind speeds, and high relative humidity; West, 2003; Herbut et al., 2018).

Cold stress defined milk production on average only during $0.4 \%$ of the experimental time. Cold stress oc-

Table 2. Evaluation of LiGAPS-Dairy for data of 3 experiments with a total of 220 Holstein-Friesian cows in the Netherlands ${ }^{1}$

\begin{tabular}{|c|c|c|c|c|}
\hline Item $^{2}$ & $\begin{array}{c}\text { Milk yield } \\
\text { per lactation }\end{array}$ & $\begin{array}{c}\text { Daily } \\
\text { milk yield }^{4}\end{array}$ & $\begin{array}{l}\text { Feed intake } \\
\text { per lactation }\end{array}$ & $\begin{array}{c}\text { Daily } \\
\text { feed intake }\end{array}$ \\
\hline Average measured ( $\mathrm{kg}$ of FPCM or DM) & $8,540(667)$ & $29.6(0.7)$ & $6,071(428)$ & $20.5(0.3)$ \\
\hline Average simulated (kg of FPCM or DM) & $8,466(187)$ & $29.7(1.1)$ & $6,228(265)$ & $21.2(0.6)$ \\
\hline Mean absolute error (kg of FPCM or DM) & $1,034(37)$ & $5.2(0.4)$ & $627(59)$ & $3.3(0.4)$ \\
\hline Relative mean absolute error ( $\% \mathrm{FPCM}$ or $\mathrm{DM})$ & $12.2(0.9)$ & $18.7(1.1)$ & $10.3(0.5)$ & $19.0(3.3)$ \\
\hline Root mean square error (kg of FPCM or DM) & $1,310(38)$ & $6.7(0.9)$ & $785(94)$ & $4.0(0.5)$ \\
\hline Slope component ( $\%$ MSE) & $5.1(3.6)$ & $13.7(3.8)$ & $0.6(0.5)$ & $25.4(6.8)$ \\
\hline Random component (\% MSE) & $63.6(10.8)$ & $50.6(12.3)$ & $74.0(14.2)$ & $41.4(5.6)$ \\
\hline Intercept equal to 0 ( $P$-value $)$ & $0.191(0.089)$ & $0.105(0.056)$ & $0.447(0.186)$ & $0.009(0.005)$ \\
\hline Slope equal to 1 ( $P$-value $)$ & $<0.001$ & $0.023(0.018)$ & $<0.001$ & $0.030(0.011)$ \\
\hline
\end{tabular}

${ }^{1}$ Values between brackets indicate SE

${ }^{2} \mathrm{FPCM}=$ fat- and protein-corrected milk; MSE = mean square error. Bias, slope, and random components of the MSE are calculated from Bibby and Toutenburg (1977); $P$-values $<0.025$ indicate significant differences (2-tailed).

${ }^{3}$ Cattle were included if at least $30 \mathrm{wk}$ of milk yield and feed intake data were available. Lactations were thus at least $30 \mathrm{wk}$, but could have been extended after the end of experiments.

${ }^{4}$ Daily milk yields are based on interpolated weekly data. 
van der Linden et al.: MODELING YIELD GAPS IN DAIRY PRODUCTION

Table 3. Potential, feed quality limited, and actual milk production with the associated yield gap and potential, feed quality limited, and actual feed efficiency (FE) with the associated productivity gap for 3 experiments with Holstein-Friesian cows conducted in the Netherlands

\begin{tabular}{|c|c|c|c|c|c|}
\hline Production level ${ }^{1}$ & Units & $\begin{array}{c}\text { All } \\
\text { experiments }\end{array}$ & 't Gen & $\begin{array}{c}\text { De Waiboerhoeve, } \\
\text { Meijer et al. } \\
(1998)\end{array}$ & $\begin{array}{c}\text { De Waiboerhoeve, } \\
\text { van Duinkerken } \\
\text { et al. }(2005)\end{array}$ \\
\hline Average potential production & kg of FPCM/lactation & 9,549 & 9,238 & 9,537 & 9,873 \\
\hline Average actual production & $\mathrm{kg}$ of FPCM/lactation & 8,540 & 7,206 & 9,234 & 9,182 \\
\hline Yield gap & $\mathrm{kg}$ of $\mathrm{FPCM} /$ lactation & 1,009 & 2,032 & 303 & 692 \\
\hline Average feed quality limited FE & $\mathrm{kg}$ of $\mathrm{FPCM} / \mathrm{kg}$ of $\mathrm{DM}$ & 1.36 & 1.43 & 1.32 & 1.34 \\
\hline Average actual FE & $\mathrm{kg}$ of $\mathrm{FPCM} / \mathrm{kg}$ of $\mathrm{DM}$ & 1.41 & 1.37 & 1.37 & 1.47 \\
\hline Productivity gap FE & $\mathrm{kg}$ of $\mathrm{FPCM} / \mathrm{kg}$ of $\mathrm{DM}$ & 0.23 & 0.35 & 0.22 & 0.15 \\
\hline Relative productivity gap & $\%$ potential $\mathrm{FE}$ & 14.2 & 20.4 & 13.8 & 9.8 \\
\hline
\end{tabular}

${ }^{1} \mathrm{FE}=$ feed efficiency; FPCM $=$ fat- and protein-corrected milk.

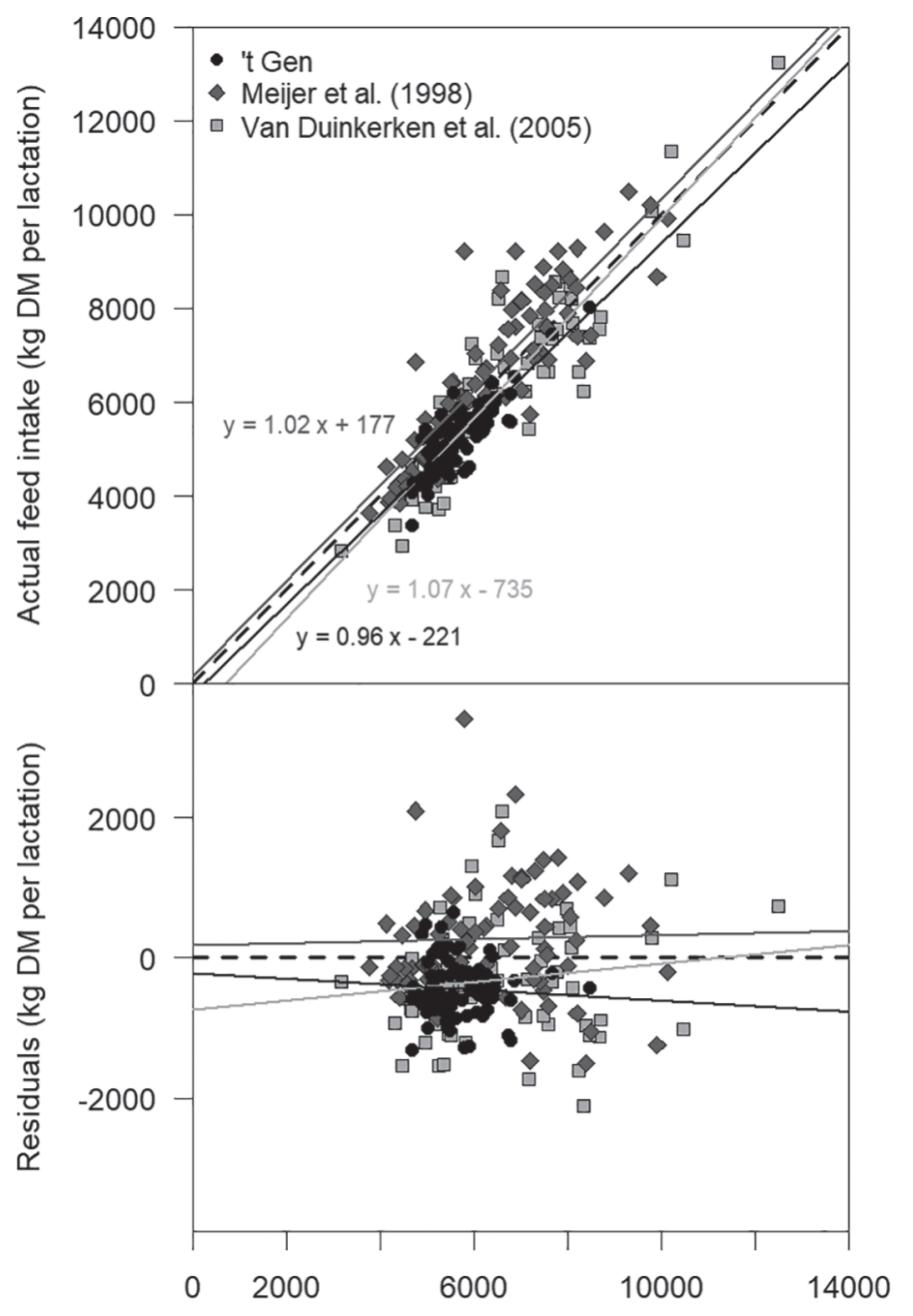

Simulated feed intake (kg DM per lactation)

Figure 3. Simulated and measured feed intake of Holstein-Friesian cattle during 3 experiments in the Netherlands. Dashed lines indicate 1:1 lines. Solid lines indicate regression lines, and their colors correspond to the colors of the experiments. curred at days when the minimum daily temperature was below $-2^{\circ} \mathrm{C}$, and most cold stress occurred below $-10^{\circ} \mathrm{C}$ (Figure 6B). These results correspond to estimates of the lower critical temperature of cattle in Europe. For example, Angrecka and Herbut (2015) indicated that the lower critical temperature for HolsteinFriesian cows in Poland was -7 to $-12^{\circ} \mathrm{C}$, depending on wind speed and milk yields.

Feed intake capacity limited milk production during $12 \%$ of the experimental time, before the peak production (Figure 5). Feed intake ( $\mathrm{kg}$ of $\mathrm{DM} / \mathrm{cow}$ per day) is affected by feed intake capacity, which is generally expressed in fill units. Fill units are included in several models to predict dry matter intake for lactating Holstein-Friesian cows, for example in the empirical model of Zom et al. (2012b).

Protein deficiency limited milk production for $34 \%$ of the experimental time, and its relative importance increased from calving up to approximately $120 \mathrm{~d}$ after calving (Figure 5). The simulated protein deficiency may be unexpected, because cattle diets were designed to avoid protein deficiency with the Dutch DVE/OEB system from 1991 (DVE = true protein digested in the intestines; OEB = degradable protein balance) $($ Tamminga et al., 1994). The simulated occurrence of protein deficiency suggests that imperfections may exist in LiGAPS-Dairy and the DVE/OEB system. Equations describing protein flows in DVE/OEB system from 1991 have been updated in 2007 and 2010, after the experiments were conducted (van Duinkerken et al., 2011). The amount of protein digested in the intestines was higher for particular feeds (e.g., grass silage) in the DVE/OEB system from 1991 compared with the system from 2007. The protein digested in the intestines might have been overestimated by the DVE/OEB system from 1991 in the experiments, which might explain a part of the protein deficiency. 
van der Linden et al.: MODELING YIELD GAPS IN DAIRY PRODUCTION

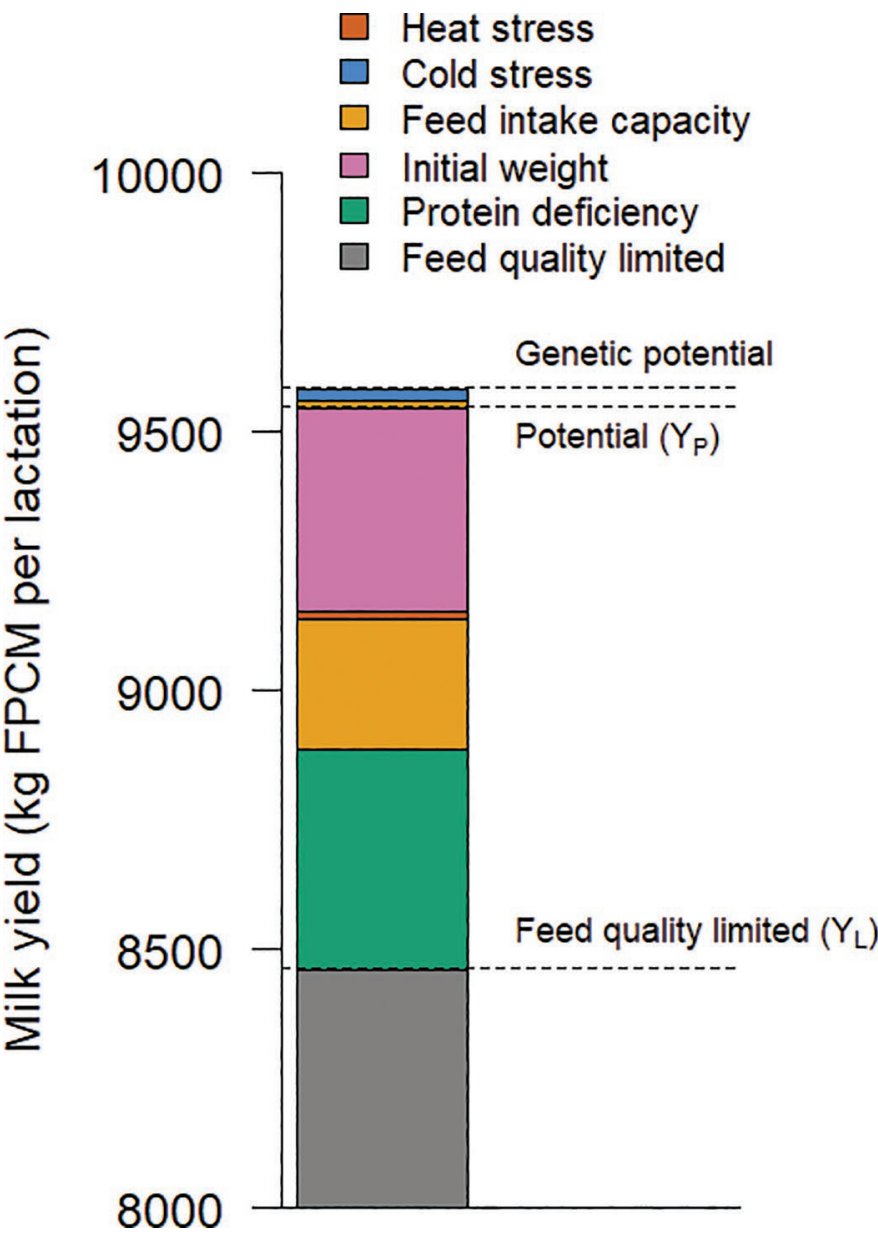

Figure 4. Analysis of the average yield gap of Holstein-Friesian dairy cows in the Netherlands. In this study, the yield gap is approximately the difference between potential production $\left(\mathrm{Y}_{\mathrm{P}}\right)$ and feed quality limited production $\left(\mathrm{Y}_{\mathrm{L}}\right)$. Cold stress defined milk production less at $Y_{L}$ than at $Y_{P}$, because of a lower-quality diet at $Y_{L}$ and an increased heat increment of feeding. The contribution of cold stress to the yield gap was negative $(-7 \mathrm{~kg} F P C M)$, which is indicated by the small difference between the dashed line for $\mathrm{Y}_{\mathrm{L}}$ and the line separating the gray and green segments. $\mathrm{FPCM}=$ fat- and protein-corrected milk.

The average protein content of diets in the experiments was $168 \mathrm{~g}$ of $\mathrm{CP} / \mathrm{kg}$ of DM (Figure 7). Average protein contents of diets ranged between 140 and $190 \mathrm{~g}$ of $\mathrm{CP} / \mathrm{kg}$ of DM in the experiment of van Duinkerken et al. (2005). Milk production of cattle on the lower side of this range might have been limited by protein deficiency, because diets containing 140 to $150 \mathrm{~g}$ of CP/ $\mathrm{kg}$ of DM are considered to be low in CP for lactating Holstein cows (Sinclair et al., 2014). In line with expectations, simulated protein deficiency mostly occurred when the $\mathrm{CP}$ content of the diet was lower than the average CP content (Figure 7).

The yield gap analysis conducted in this study identified which biophysical factors defined and limited milk production, to what extent, and when (Figures 4 and $5)$. The biophysical factors that define and limit milk production are broadly known for Dutch dairy systems, where emphasis is put on breeding to increase potential production and improved feeding to mitigate yield gaps. The novelty of the model thus lies in the quantification
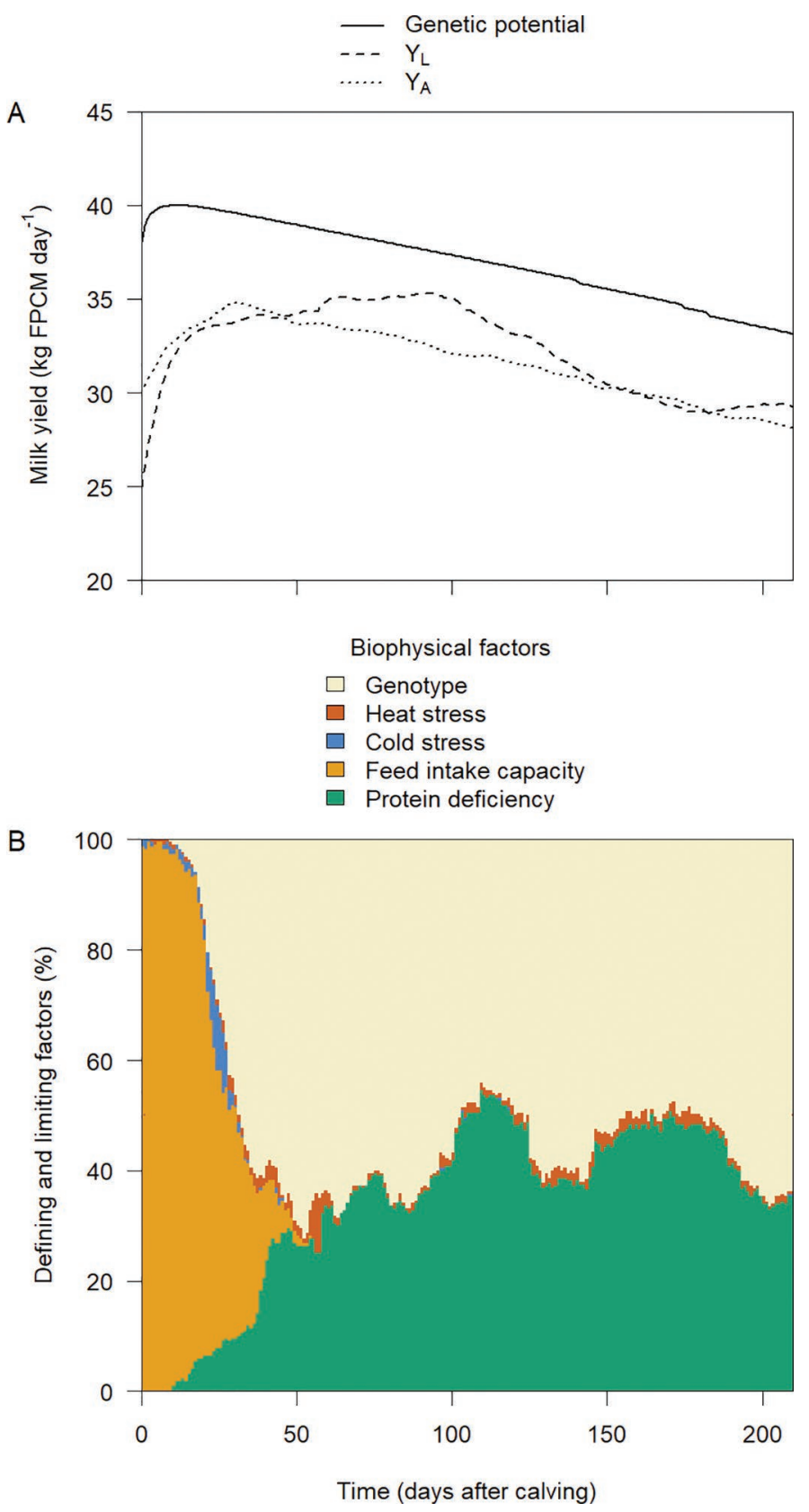

Figure 5. Average milk yields according to the genetic potential, and under feed quality limited $\left(\mathrm{Y}_{\mathrm{L}}\right)$ and actual production $\left(\mathrm{Y}_{\mathrm{A}}\right)$ of 220 Holstein-Friesian cows in their first $210 \mathrm{~d}$ after calving in experiments (A) and the biophysical factors defining and limiting milk production under feed quality limited production (B). FPCM = fat- and proteincorrected milk. 


\section{van der Linden et al.: MODELING YIELD GAPS IN DAIRY PRODUCTION}

of the contribution of individual factors to the yield gap and their occurrence over time.

Effects of reducing factors, diseases and stress, were not assessed because experimental data only included clinically healthy cows. If the model is applied to dif-
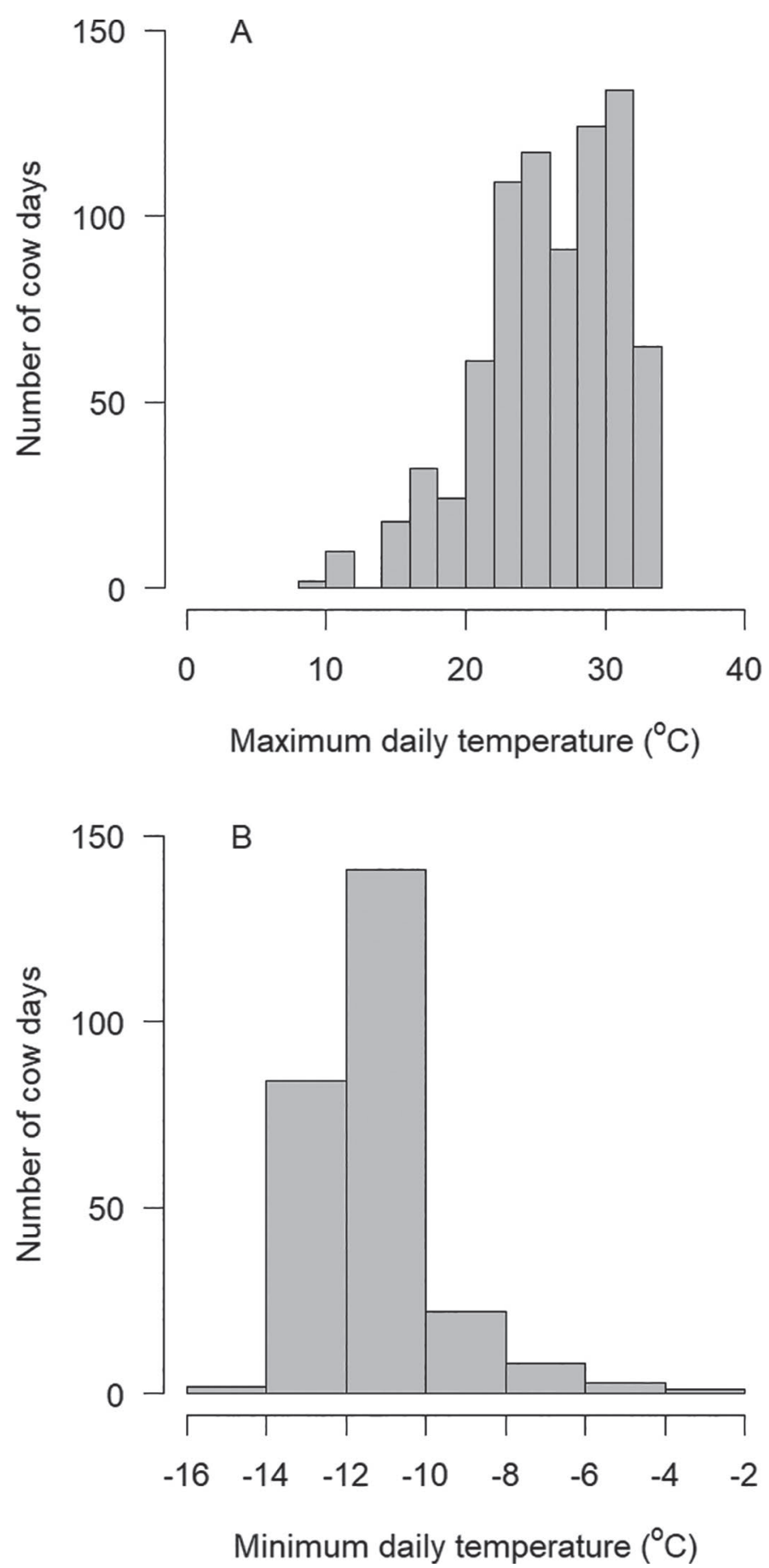

Figure 6. Number of cow days where heat stress (A) or cold stress (B) defined milk production of Holstein-Friesian cows $(\mathrm{n}=220)$ under feed quality limited production. ferent conditions where diseases and stress are known to reduce milk production, the model can be used to assess effects of these reducing factors too. The part of the yield gap explained by reducing factors can be calculated as the difference between feed-limited production and $\mathrm{Y}_{\mathrm{A}}$ (van de Ven et al., 2003). Although beyond the scope of this model illustration, the outcomes of yield gap analysis can be used to specify and explore improvement options to increase resource use efficiency and mitigate yield gaps (van Ittersum et al., 2013; Mayberry et al., 2017; Silva et al., 2017). Besides biophysical factors, socioeconomic, cultural, and ethical factors have to be taken into account in yield gap mitigation. This explains why crop production levels plateau at 75 to $85 \%$ of potential production (Cassman et al., 2003; van Ittersum et al., 2013). Especially for livestock, yield gap analysis has to be placed in a wider ethical context, that allows to eliminate improvement options compromising animal welfare and environmental goals (Garnett et al., 2013).

\section{Future Steps}

The model evaluation presented for Holstein-Friesian cows in the Netherlands is an important step in the

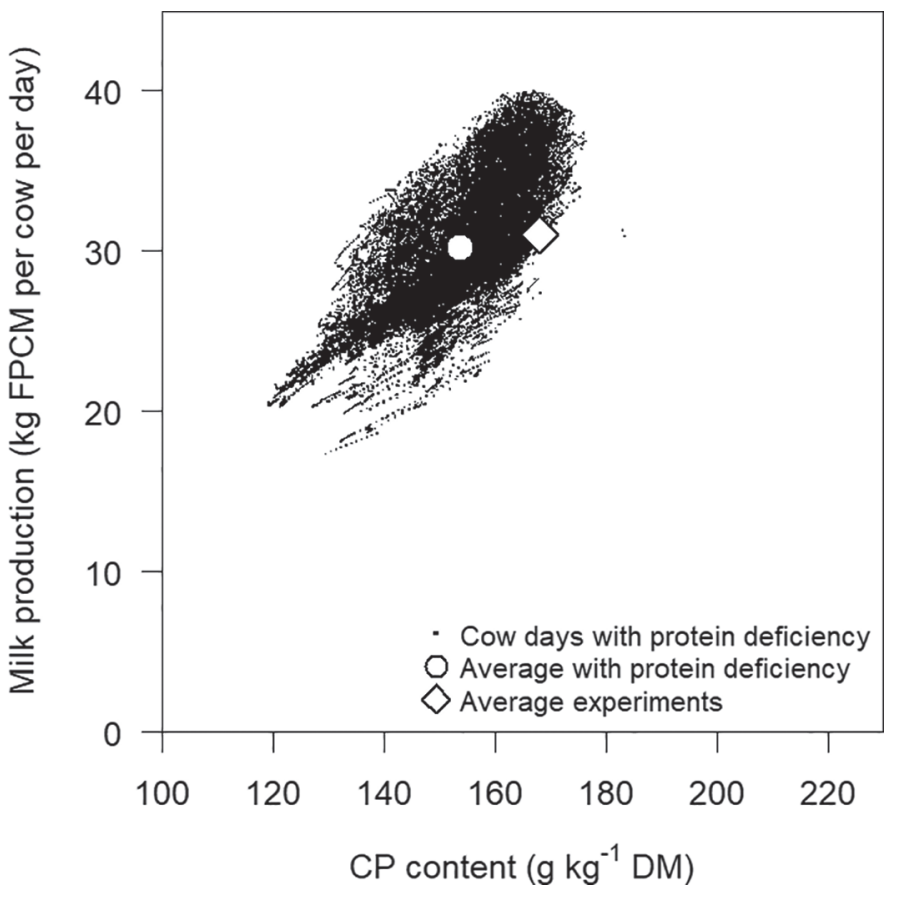

Figure 7. Crude protein content of diets versus milk production under feed quality limited production. The large circle indicates the average $\mathrm{CP}$ content for all cow days with protein deficiency (black dots). The diamond indicates the average milk production for all days in the experiment, irrespective of the occurrence of protein deficiency. $\mathrm{FPCM}=$ fat- and protein-corrected milk. 
evaluation of a model that is designed to be generic and applicable to different dairy production systems across the globe. Obvious next steps in model evaluation would be to evaluate the model for different production systems, countries, and breeds. Model evaluation was conducted for cows permanently housed in stables, whereas the majority of Dutch dairy cows graze on pasture during parts of the year. A challenge in simulating dairy cows that are kept on pasture lies in obtaining accurate input parameters and variables for LiGAPSDairy. Feed quality is an important input for the model, but the quality of grass consumed on pasture is often unknown, and varies throughout the year (Stergiadis et al., 2015). In addition, the model may overestimate grass intake at low sward height, because it does not account for interactions between the animal and the grass. A priority in future research, therefore, is model evaluation for data-rich grazing systems, and inclusion of interactions between animals and grass.

In the present paper, model evaluation was conducted with experimental data for individual cows over a period of 1 lactation of at least $30 \mathrm{wk}$ up to a time period of 4 lactations. The total lifetime productivity of cows was not investigated, because data for such long-term experiments are lacking. The model LiGAPS-Dairy can simulate milk production; however, for a complete life span from birth of a calf to slaughter of an adult cow. We assume a cow's life span can be simulated adequately as well, because the evaluation already included time periods of 1 up to 4 lactations. In addition, model users can scale up from an individual animal to the herd level similarly to LiGAPS-Beef. This allows to account for milk production by cows and for beef production from cull cows and calves.

The model LiGAPS-Dairy was not developed to simulate the daily fat and protein contents of milk as a function of genotype, climate, feed quality, and available feed quantity. Instead, FPCM production was calculated from empirical equations (Equations 3 and 4). Future research may focus, therefore, on simulating milk quality by adopting, for example, more mechanistic equations for Holstein-Friesian cows from Daniel et al. (2016).

Because the livestock sector accounts for $14.5 \%$ of the anthropogenic greenhouse gas (GHG) emissions (Gerber et al., 2013), extension of LiGAPS-Dairy with equations for GHG emissions will be relevant. The present model, however, did not focus on inclusion of enteric $\mathrm{CH}_{4}$ emissions and $\mathrm{CH}_{4}$ and $\mathrm{N}_{2} \mathrm{O}$ emissions from manure. Inclusion would allow to calculate GHG emissions per $\mathrm{kg}$ of FPCM (i.e., emission intensity) under potential and feed-limited production, which provides insights in synergies and trade-offs between milk production and GHG emissions.
Finally, future research could link diet composition to competition for arable land between food and feed production. The diet under potential production included $31.8 \%$ wheat, which may be partially food grade quality. The diet under feed quality limited production and actual production hardly included human-edible constituents. Diets containing larger percentages of human-edible ingredients result in more food-feed competition (van Zanten et al., 2018). Feeding human-edible ingredients to cows may thus result in a higher milk production per lactation and a higher feed efficiency at a dairy farm, but it may decrease food production at larger scales (e.g., regional or national level).

\section{CONCLUSIONS}

The mechanistic model LiGAPS-Dairy was developed from an existing model to quantify and analyze yield gaps in dairy production systems, which is defined as the difference between the potential and actual milk production per lactation. After evaluation of the model with experimental data from the Netherlands, we classified its performance as acceptable. Average relative yield gaps were estimated to be approximately $11 \%$ of $Y_{P}$ and were mainly explained by protein deficiency, cow weight at the start of experiments, feed intake capacity, and heat stress. LiGAPS-Dairy identified the genotype as the most important defining factor for milk production (53\% of cow days in experiments) under feed quality limited production, and protein deficiency as the most limiting factor (34\% of cow days in experiments). Hence, the model can be used to identify which factors define and limit milk production, to what extent, and when during lactation. This opens possibilities to explore management strategies relating to heat stress and protein deficiency to increase milk production and feed efficiency. Next steps are evaluation of the model for dairy production systems in other countries than the Netherlands, and exploration of management strategies.

\section{ACKNOWLEDGMENTS}

The authors are grateful to the World Bank Group, Washington, DC, and the Graduate School of Production Ecology and Resource Conservation for financially supporting this study. This study was part of the World Bank Project Investing in Sustainable Livestock (Grant number P160021). We thank Gert van Duinkerken (Wageningen Livestock Research, Wageningen University \& Research) for provision of experimental data for dairy cows in Lelystad, the Netherlands. The authors have not stated any conflicts of interest. 


\section{REFERENCES}

André, G., B. Engel, P. B. M. Berentsen, T. V. Vellinga, and A. G. J. M. Oude Lansink. 2011. Quantifying the effect of heat stress on daily milk yield and monitoring dynamic changes using an adaptive dynamic model. J. Dairy Sci. 94:4502-4513. https://doi.org/ 10.3168/jds.2010-4139.

Angrecka, S., and P. Herbut. 2015. Conditions for cold stress development in dairy cattle kept in free stall barn during severe frosts. Czech J. Anim. Sci. 60:81-87. https://doi.org/10.17221/7978 -CJAS.

Bellocchi, G., M. Rivington, M. Donatelli, and K. Matthews. 2010. Validation of biophysical models: Issues and methodologies. A review. Agron. Sustain. Dev. 30:109-130. https://doi.org/10.1051/ agro/2009001.

Bennett, N. D., B. F. W. Croke, G. Guariso, J. H. A. Guillaume, S. H. Hamilton, A. J. Jakeman, S. Marsili-Libelli, L. T. H. Newham, J. P. Norton, C. Perrin, S. A. Pierce, B. Robson, R. Seppelt, A. A. Voinov, B. D. Fath, and V. Andreassian. 2013. Characterising performance of environmental models. Environ. Model. Softw. 40:1-20. https://doi.org/10.1016/j.envsoft.2012.09.011.

Bibby, J., and H. Toutenburg. 1977. Prediction and Improved Estimation in Linear Models. John Wiley \& Sons, London, United Kingdom.

Britt, J. H., R. A. Cushman, C. D. Dechow, H. Dobson, P. Humblot, M. F. Hutjens, G. A. Jones, P. S. Ruegg, I. M. Sheldon, and J. S. Stevenson. 2018. Invited review: Learning from the future-A vision for dairy farms and cows in 2067. J. Dairy Sci. 101:3722-3741. https://doi.org/10.3168/jds.2017-14025.

Cassman, K. G., A. Dobermann, D. T. Walters, and H. Yang. 2003. Meeting cereal demand while protecting natural resources and improving environmental quality. Annu. Rev. Environ. Resour. 28:315-358. https://doi.org/10.1146/annurev.energy.28.040202 .122858 .

CSIRO. 2007. Nutrient Requirements of Domesticated Ruminants. CSIRO Publishing, Collingwood, Australia.

CVB. 2016. Tabellenboek Veevoeding 2016 - Voedernormen rundvee, schapen, geiten en voederwaarden voedermiddelen voor herkauwers. CVB. Accessed June 2, 2020. http://www.cvbdiervoeding.nl/ pagina/10081/downloads.aspx.

Daniel, J. B., N. C. Friggens, P. Chapoutot, H. van Laar, and D. Sauvant. 2016. Milk yield and milk composition responses to change in predicted net energy and metabolizable protein: A meta-analysis. Animal 10:1975-1985. https://doi.org/10.1017/ S1751731116001245.

Domecq, J. J., A. L. Skidmore, J. W. Lloyd, and J. B. Kaneene. 1995. Validation of body condition scores with ultrasound measurements of subcutaneous fat of dairy cows. J. Dairy Sci. 78:2308-2313. https://doi.org/10.3168/jds.S0022-0302(95)76857-6.

Emmans, G. C. 1988. Genetic components of potential and actual growth. BSAP Occas. Publ. 12:153-181. https://doi.org/10.1017/ S0263967X00003347.

Emmans, G. C. 1997. A method to predict the food intake of domestic animals from birth to maturity as a function of time. J. Theor. Biol. 186:189-199. https://doi.org/10.1006/jtbi.1996.0357.

Garnett, T., M. C. Appleby, A. Balmford, I. J. Bateman, T. G. Benton, P. Bloomer, B. Burlingame, M. Dawkins, L. Dolan, D. Fraser, M. Herrero, I. Hoffmann, P. Smith, P. K. Thornton, C. Toulmin, S. J. Vermeulen, and H. C. J. Godfray. 2013. Sustainable intensification in agriculture: Premises and policies. Science 341:33-34. https: //doi.org/10.1126/science.1234485.

Gerber, P. J., H. Steinfeld, B. Henderson, A. Mottet, C. Opio, J. Dijkman, A. Falcucci, and G. Tempio. 2013. Tackling Climate Change through Livestock - A Global Assessment of Emissions and Mitigation Opportunities. Food and Agriculture Organization of the United Nations, Rome, Italy.

Gerber, P. J., T. V. Vellinga, C. Opio, and H. Steinfeld. 2011. Productivity gains and greenhouse gas emissions intensity in dairy systems. Livest. Sci. 139:100-108. https://doi.org/10.1016/j.livsci .2011.03.012.
Hastie, T., R. Tibshirani, and J. Friedman. 2009. The Elements of Statistical Learning - Data Mining, Inference, and Prediction. 2nd ed. Springer, New York, NY.

Herbut, P., S. Angrecka, and J. Walczak. 2018. Environmental parameters to assessing of heat stress in dairy cattle - A review. Int. J. Biometeorol. 62:2089-2097. https://doi.org/10.1007/s00484-018 -1629-9.

Jarrige, R., C. Demarquilly, J. P. Dulphy, A. Hoden, J. Robelin, C. Beranger, Y. Geay, M. Journet, C. Malterre, D. Micol, and M. Petit. 1986. The INRA fill unit system for predicting the voluntary intake of forage-based diets in ruminants - a review. J. Anim. Sci. 63:1737-1758. https://doi.org/10.2527/jas1986.6361737x.

Johnson, I. R., J. France, and B. R. Cullen. 2016. A model of milk production in lactating dairy cows in relation to energy and nitrogen dynamics. J. Dairy Sci. 99:1605-1618. https://doi.org/10.3168/jds .2015-10068.

Journet, M., and B. Remond. 1976. Physiological factors affecting the voluntary intake of feed by cows: A review. Livest. Prod. Sci. 3:129-146. https://doi.org/10.1016/0301-6226(76)90030-0.

KNMI. 2019. Daggegevens van het weer in Nederland - Download. Accessed Apr. 4, 2019. http://projects.knmi.nl/klimatologie/ daggegevens/selectie.cgi.

Lawrence, T. E., N. A. Elam, M. F. Miller, J. C. Brooks, G. G. Hilton, D. L. VanOverbeke, F. K. McKeith, J. Killefer, T. H. Montgomery, D. M. Allen, D. B. Griffin, R. J. Delmore, W. T. Nichols, M. N. Streeter, D. A. Yates, and J. P. Hutcheson. 2010. Predicting red meat yields in carcasses from beef-type and calf-fed Holstein steers using the United States Department of Agriculture calculated yield grade. J. Anim. Sci. 88:2139-2143. https://doi.org/10 $.2527 /$ jas.2009-2739.

Mayberry, D., A. Ash, D. Prestwidge, C. M. Godde, B. Henderson, A. Duncan, M. Blummel, Y. Ramana Reddy, and M. Herrero. 2017. Yield gap analyses to estimate attainable bovine milk yields and evaluate options to increase production in Ethiopia and India. Agric. Syst. 155:43-51. https://doi.org/10.1016/j.agsy.2017.04.007.

Meijer, R. G. M., T. Boxem, and W. J. A. Hanekamp. 1998. Voeding en management hoogproductieve veestapel - Hoogproductiebedrijf Waiboerhoeve. Praktijkonderzoek Rundvee, Schapen en Paarden, Lelystad, the Netherlands.

Mertens, D. R. 1997. Creating a system for meeting the fiber requirements of dairy cows. J. Dairy Sci. 80:1463-1481. https://doi.org/ 10.3168/jds.S0022-0302(97)76075-2.

NRC (National Research Council). 2001. Nutrient Requirements of Dairy Cattle. 7th revised edition. National Academies Press, Washington, D.C.

Peterson, A. T., J. Soberón, R. G. Pearson, R. P. Anderson, E. Martínez-Meyer, M. Nakamura, and M. B. Araújo. 2011. Ecological Niches and Geographic Distributions. Vol. 49. Monographs in Population Biology. Princeton University Press, Princeton, NJ.

Pires, J. A. A., C. Delavaud, Y. Faulconnier, D. Pomies, and Y. Chilliard. 2013. Effects of body condition score at calving on indicators of fat and protein mobilization of periparturient Holstein-Friesian cows. J. Dairy Sci. 96:6423-6439. https://doi.org/10.3168/jds.2013 $-6801$.

R Core Team. 2013. R: A Language and Environment for Statistical Computing. R Foundation for Statistical Computing, Vienna, Austria.

Roche, J. R., N. C. Friggens, J. K. Kay, M. W. Fisher, K. J. Stafford, and D. P. Berry. 2009. Invited review: Body condition score and its association with dairy cow productivity, health, and welfare. J. Dairy Sci. 92:5769-5801. https://doi.org/10.3168/jds.2009-2431.

Rufino, M. C., M. Herrero, M. T. Van Wijk, L. Hemerik, N. De Ridder, and K. E. Giller. 2009. Lifetime productivity of dairy cows in smallholder farming systems of the Central highlands of Kenya. Animal 3:1044-1056. https://doi.org/10.1017/S1751731109004248.

Silva, J. V., P. Reidsma, A. G. Laborte, and M. K. van Ittersum. 2017. Explaining rice yields and yield gaps in Central Luzon, Philippines: An application of stochastic frontier analysis and crop modelling. Eur. J. Agron. 82:223-241. https://doi.org/10.1016/j .eja.2016.06.017. 


\section{van der Linden et al.: MODELING YIELD GAPS IN DAIRY PRODUCTION}

Sinclair, K. D., P. C. Garnsworthy, G. E. Mann, and L. A. Sinclair. 2014. Reducing dietary protein in dairy cow diets: Implications for nitrogen utilization, milk production, welfare and fertility. Animal 8:262-274. https://doi.org/10.1017/S1751731113002139.

Stergiadis, S., M. Allen, X. J. Chen, D. Wills, and T. Yan. 2015. Prediction of nutrient digestibility and energy concentrations in fresh grass using nutrient composition. J. Dairy Sci. 98:3257-3273. https://doi.org/10.3168/jds.2014-8587.

Sutton, J. D. 1989. Altering milk composition by feeding. J. Dairy Sci. 72:2801-2814. https://doi.org/10.3168/jds.S0022-0302(89)79426 -1 .

Tamminga, S., W. M. van Straalen, A. P. J. Subnel, R. G. M. Meijer, A. Steg, C. J. G. Wever, and M. C. Blok. 1994. The Dutch protein evaluation system: the DVE/OEB-system. Livest. Prod. Sci. 40:139-155. https://doi.org/10.1016/0301-6226(94)90043-4.

Tedeschi, L. O., L. F. L. Cavalcanti, M. A. Fonseca, M. Herrero, and P. K. Thornton. 2014. The evolution and evaluation of dairy cattle models for predicting milk production: An agricultural model intercomparison and improvement project (AgMIP) for livestock. Anim. Prod. Sci. 54:2052-2067. https://doi.org/10.1071/AN14620.

Tedeschi, L. O., W. Chalupa, E. Janczewski, D. G. Fox, C. Sniffen, R. Munson, P. J. Kononoff, and R. Boston. 2008. Evaluation and application of the CPM dairy nutrition model. J. Agric. Sci. 146:171182. https://doi.org/10.1017/S0021859607007587.

Timmerman, M., K. Van Reenen, H. Holster, and A. Evers. 2018. Verkennende Studie Naar Hittestress Bij Melkvee Tijdens Weidegang in Gematigde Klimaatstreken. Wageningen Livestock Research, the Netherlands. http://library.wur.nl/WebQuery/ wurpubs/fulltext/460412.

van de Ven, G. W. J., N. de Ridder, H. van Keulen, and M. K. van Ittersum. 2003. Concepts in production ecology for analysis and design of animal and plant-animal production systems. Agric. Syst. 76:507-525. https://doi.org/10.1016/S0308-521X(02)00110-5.

van der Linden, A. 2021. Supplemental Material "Yield gap analysis in dairy production systems using the mechanistic model LiGAPS-Dairy.". Mendeley Data V1. https://doi.org/10.17632/ kndd25m5y3.1.

van der Linden, A., S. J. Oosting, G. W. J. van de Ven, I. J. M. De Boer, and M. K. Van Ittersum. 2015. A framework for quantitative analysis of livestock systems using theoretical concepts of production ecology. Agric. Syst. 139:100-109. https://doi.org/10.1016/j .agsy.2015.06.007.

van der Linden, A., G. W. J. van de Ven, S. J. Oosting, M. K. van Ittersum, and I. J. M. de Boer. 2019a. LiGAPS-Beef, a mechanistic model to explore potential and feed-limited beef production 1: Model description and illustration. Animal 13:845-855. https:// doi.org/10.1017/S1751731118001726.

van der Linden, A., G. W. J. van de Ven, S. J. Oosting, M. K. Van Ittersum, and I. J. M. De Boer. 2019b. LiGAPS-Beef, a mechanistic model to explore potential and feed-limited beef production 2: Sensitivity analysis and evaluation of sub-models. Animal 13:856-867. https://doi.org/10.1017/S1751731118001738.

van der Linden, A., G. W. J. van de Ven, S. J. Oosting, M. K. Van Ittersum, and I. J. M. De Boer. 2019c. LiGAPS-Beef, a mechanistic model to explore potential and feed limited beef production 3: Model evaluation. Animal 13:868-878. https://doi.org/10.1017/ S1751731118002641.

van Duinkerken, G., G. Andre, M. C. J. Smits, G. J. Monteny, and L. B. J. Sebek. 2005. Effect of rumen-degradable protein balance and forage type on bulk milk urea concentration and emission of ammonia from dairy cow houses. J. Dairy Sci. 88:1099-1112. https:// doi.org/10.3168/jds.S0022-0302(05)72777-6.

van Duinkerken, G., M. C. Blok, A. Bannink, J. W. Cone, J. Dijkstra, A. van Vuuren, and S. Tamminga. 2011. Update of the Dutch protein evaluation system for ruminants: The DVE/OEB 2010 system. J. Agric. Sci. 149:351-367. https://doi.org/10.1017/ S0021859610000912.

van Ittersum, M. K., K. G. Cassman, P. Grassini, J. Wolf, P. Tittonell, and Z. Hochman. 2013. Yield gap analysis with local to global relevance-A review. Field Crops Res. 143:4-17. https://doi.org/10 .1016/j.fcr.2012.09.009.

van Zanten, H. H. E., M. Herrero, O. Van Hal, E. Röös, A. Muller, T. Garnett, P. J. Gerber, C. Schader, and I. J. M. De Boer. 2018. Defining a land boundary for sustainable livestock consumption. Glob. Chang. Biol. 24:4185-4194. https://doi.org/10.1111/gcb .14321.

VandeHaar, M. J., and J. R. Black. 1991. Ration formulation using linear-programming. Vet. Clin. North Am. Food Anim. Pract. 7:541-556. https://doi.org/10.1016/S0749-0720(15)30788-X.

Veerkamp, R. F., L. Kaal, Y. de Haas, and J. D. Oldham. 2013. Breeding for robust cows that produce healthier milk: RoBUsTMilK. Adv. Anim. Biosci. 4:594-599. https://doi.org/10.1017/ S2040470013000149.

Wellock, I. J., G. C. Emmans, and I. Kyriazakis. 2003. Modelling the effects of thermal environment and dietary composition on pig performance: Model logic and concepts. Anim. Sci. 77:255-266. https://doi.org/10.1017/S1357729800058999.

West, J. W. 2003. Effects of heat-stress on production in dairy cattle. J. Dairy Sci. 86:2131-2144. https://doi.org/10.3168/jds.S0022 -0302(03)73803-X.

Wood, P. D. P. 1967. Algebraic model of the lactation curve in cattle. Nature 216:164-165. https://doi.org/10.1038/216164a0.

Yan, T., C. S. Mayne, D. C. Patterson, and R. E. Agnew. 2009. Prediction of body weight and empty body composition using body size measurements in lactating dairy cows. Livest. Sci. 124:233-241. https://doi.org/10.1016/j.livsci.2009.02.003.

Zom, R. L. G., G. André, and A. M. van Vuuren. 2012a. Development of a model for the prediction of feed intake by dairy cows 2. Evaluation of prediction accuracy. Livest. Sci. 143:58-69. https://doi .org/10.1016/j.livsci.2011.08.013.

Zom, R. L. G., G. Andre, and A. M. van Vuuren. 2012b. Development of a model for the prediction of feed intake by dairy cows: 1 . Prediction of feed intake. Livest. Sci. 143:43-57. https://doi.org/10 .1016/j.livsci.2011.08.014.

\section{ORCIDS}

Aart van der Linden () https://orcid.org/0000-0002-2363-356X Gerrie W. J. van de Ven ( https://orcid.org/0000-0001-5693-0280 Martin K. van Ittersum @ https://orcid.org/0000-0001-8611-6781 Imke J. M. de Boer (ㄴ) https://orcid.org/0000-0002-0675-7528

\section{APPENDIX}

The R-code of LiGAPS-Dairy is published open source at the model portal of the Plant Production Systems group of Wageningen University \& Research, the Netherlands (https://models.pps.wur.nl/models). Supplemental Material to this paper can be found on Mendeley Data (http://dx.doi.org/10.17632/kndd25m5y3 .1, van der Linden, 2021). 